\title{
Targeting Endoplasmic Reticulum Stress as an Effective Treatment for Alcoholic Pancreatitis
}

\author{
Hui Li ${ }^{1}$, Wen Wen ${ }^{1}$, Jia Luo ${ }^{1,2, \#}$
}

1. Department of Pathology, University of lowa Carver College of Medicine, lowa City, IA 52242, USA

2. Iowa City VA Health Care System, lowa City, IA 52246, USA

\# Correspondence author: Jia Luo, Ph.D., Department of Pathology, University of lowa Carver College of Medicine, lowa City, IA 52242; Email: jia-luo@uiowa.edu; Tel: 319-335-2256

Key words: Alcohol abuse; cell signaling; FDA-approved drugs; oxidative stress; therapy

\section{Abbreviations:}

AP, acute pancreatitis

$\mathrm{CP}$, chronic pancreatitis

ER, endoplasmic reticulum

UPR, unfolded protein response

EPI, exocrine pancreatic insufficiency

PC, pancreatic cancer

DM, diabetes mellitus

CLDN2, clauding 2

CTRB1, chymotrypsin B1

CTRB2, chymotrypsin B2 
ALDH2, aldehyde dehydrogenase-2

ADH1B, alcohol dehydrogenase-1B

ALD, alcoholic liver disease

$\mathrm{ALT}$, alanine aminotransferase

AST, aspartate aminotransferase

LPS, lipopolysaccharides

CPA1, carboxypeptidase A1

TPP, thiamine pyrophosphate

ROS, reactive oxygen species

CFTR, cystic fibrosis transmembrane conductance regulator

IRE1, inositol-requiring kinase 1

PERK, protein kinase-like ER kinase

GRP78, 78-kDa glucose regulated protein

elF2, eukaryotic translation initiation factor-2

$\mathrm{XBP} 1, \mathrm{X}$ box-binding protein 1

ERAD, ER-associated degradation

RIDD, IRE1-dependent RNA decay

ATF6, activating transcription factor 6

ATF4, activating transcription factor 4

CHOP, C/EBP homologous protein

GADD34, growth arrest and DNA damage-inducible protein 34

MANF, mesencephalic astrocyte-derived neurotrophic factor

hPAC, human pancreatic acinar cells

ERAD, ER-associated degradation

4-PBA, sodium phenylbutyrate

UDCA, ursodeoxycholic acid 
TUDCA, tauroursodeoxycholic acid

CCK-8, cholecystokinin-8

$\mathrm{GA}$, guanabenz acetate

TZD, trazodone

DBM, dibenzoylmethane

ALS, amyotrophic lateral sclerosis

OPMD, oculopharyngeal muscular dystrophy

HSPs, hereditary spastic paraplegias

$\mathrm{SCl}$, spinal cord injury

AA 147, compound 147

AA 263, compound 263

CRAC, calcium release-activated calcium channel

$\mathrm{AAV}$, adeno-associated virus

DA, nigral dopamine 


\begin{abstract}
Pancreatitis and alcoholic pancreatitis are serious health concerns, and there is an urgent need for effective treatment strategies. Alcohol is a known etiological factor for pancreatitis, including acute pancreatitis (AP) and chronic pancreatitis (CP). Excessive alcohol consumption induces many pathological stress responses; of particular note is endoplasmic reticulum (ER) stress and adaptive unfolded protein response (UPR). ER stress results from the accumulation of unfolded/misfolded protein in the ER and is implicated in the pathogenesis of alcoholic pancreatitis. Here we summarize the possible mechanisms by which ER stress contributes to alcoholic pancreatitis. We also discuss potential approaches targeting ER stress and UPR for developing novel therapeutic strategies for the disease.
\end{abstract}

\title{
Acute and chronic pancreatitis
}

Pancreatitis is a common inflammatory disorder of the pancreas and is associated with high mortality and healthcare burdens worldwide ${ }^{1,2}$. It mainly consists of two forms: acute pancreatitis (AP) and chronic pancreatitis $(C P)$. AP is the most frequent cause of gastrointestinal disorders requiring hospitalization in the US, and its associated inpatient care cost is about \$2.6 billion annually ${ }^{2-4}$. Although less frequent, CP also causes significant morbidity and financial burden ${ }^{3}$. Additionally, the incidence of pancreatitis differs with age and gender. The risk of developing AP increases with age ${ }^{5,6}$, whereas CP is more common in middle-aged people ${ }^{2}$. Furthermore, AP does not appear to differ between men and women ${ }^{6}$, but CP is more common in men than women ${ }^{2,7}$. AP and CP share a significant portion of clinical manifestations and phenotypes but also have distinct morphological and imaging features.

AP is characterized by sudden abdominal pain, elevated levels of pancreatic enzymes in the blood, and imaging evidence of pancreatic inflammation ${ }^{8,9}$. Depending on the clinical features, AP can be classified into mild, moderate, or severe forms. The most common form of AP is mild AP, which can be self-healed within weeks. However, the moderate and severe forms 
can progress into necrotizing pancreatitis, which has a $20-40 \%$ mortality rate ${ }^{10}$. A variety of longterm sequelae have been reported that can persist beyond hospital admission of AP. AP may increase the risk of other pancreatic disorders, including $\mathrm{CP}$, exocrine pancreatic insufficiency (EPI), pancreatic cancer (PC) and diabetes mellitus (DM). 17\% of AP patients are re-admitted after the first episode for recurrent pancreatitis, and about $8 \%$ of patients progress to CP ${ }^{11,12}$. Approximately one quarter to one third of AP patients develop EPI during the follow-up period ${ }^{13}$, 14. The prevalence of EPI following AP is higher with the severe form than with the mild form, and it is higher in patients with an etiology of alcohol than one of gallstones ${ }^{14}$. AP patients often develop prediabetes and/or DM after being discharged from the hospital ${ }^{15,16}$. The diagnosis of AP increases the risk of $P C$, and a higher risk of $P C$ is associated with an increased number of recurrent episodes of AP ${ }^{17,18}$.

$\mathrm{CP}$ is believed to result from the recurrence of $\mathrm{AP}$, which leads to chronic pain, pancreatic atrophy, duct strictures and calcifications ${ }^{19,20}$. Although less common than AP, CP significantly affects patients' quality of life due to irreversible and debilitating injuries to the function of the pancreas. $\mathrm{CP}$ is also associated with other pancreatic diseases. It has been reported that CP increases the risk of EPI ${ }^{21,22}, \mathrm{PC}^{23,24}$ and $\mathrm{DM}^{25,26}$. The high disease burden of AP and CP underscores the importance of identifying predisposing factors, understanding pathogenesis and developing therapeutic intervention for these diseases.

\section{Alcohol consumption and pancreatitis}

Alcohol exposure is a known etiological factor for both AP and CP. Epidemiological studies have shown that excessive alcohol consumption is the second leading cause of AP after gallstones ${ }^{1,27}$ and is the most prevalent risk factor for $\mathrm{CP}{ }^{28}$. Alcohol abuse is also a risk factor for the recurrence of $A P$ and increases the chances of progression of AP to CP ${ }^{11,29}$. Although alcohol can contribute to the initiation and progression of pancreatitis, only a small number of 
heavy alcohol drinkers develop the disease, suggesting that other disposing factors are involved in the development of alcohol-related pancreatitis ${ }^{30-33}$.

The association between alcohol consumption and pancreatitis is evaluated predominantly by self-reported survey studies. Corrao et al. conducted a meta-analysis of studies published between 1966 and 1995 and showed that the risk of pancreatitis monotonically increased with increasing alcohol consumption ${ }^{34}$. Consistent with this finding, Irving et al. analyzed research published between 1980 and 2008 and confirmed a monotonic dose-response relationship between alcohol consumption and the risk of pancreatitis, with a threshold of 4 drinks daily that significantly increased the risk of pancreatitis ${ }^{35}$. Similarly, more recent studies indicated that prolonged use of alcohol with a threshold level of 4-5 drinks per day was required for an increased risk of pancreatitis ${ }^{19,36-39}$. In addition, the amount of recently-consumed alcohol was shown to determine the severity of the first episode of acute alcoholic pancreatitis ${ }^{40}$. In the absence of long-term use, binge drinking alone did not increase the incidence of AP ${ }^{41}$. Regular consumption of alcohol at lower levels, however, appeared to have an inconsistent effect on pancreatitis. Some reported that low alcohol drinking $(<50$ gram per day) increased the recurrence of $\mathrm{AP}$ and accelerated the progression of $\mathrm{CP}{ }^{42,43}$. Others even found that mild or moderate drinking was inversely associated with an increased risk of pancreatitis ${ }^{44}$.

In contrast to prolonged heavy alcohol consumption that has been known as a risk factor for pancreatitis, alcohol abstinence has been shown to slow down the progression of pancreatitis and reduce the recurrence of AP. For example, withholding from drinking resolved abdominal pain and slowed the deterioration of pancreatic function in chronic heavy drinkers ${ }^{45}$. Abstinence after the first episode of AP minimized the number of recurrent attacks of $A P{ }^{46}$. Similarly, in an effort to determine the risk factors associated with recurrent pancreatitis, Pelli et al. showed that abstinence from alcohol protected against recurrence of $\mathrm{AP}{ }^{47}$.

Alcohol can also act as a co-factor to increase the sensitivity of the pancreas to the detrimental effect of other risk factors including environmental and dietary factors ${ }^{48}$. Cigarette 
smoking is an independent risk factor for a number of pancreatic disorders, including $\mathrm{AP}{ }^{49}, \mathrm{CP} 50$ and PC 51,52. Alcohol drinking can accelerate the progression of cigarette smoking-related pancreatitis and vice versa, suggesting a synergistic interaction of alcohol and smoking in the development of the disease ${ }^{53-56}$. Hypertriglyceridemia, referring to an elevated blood level of triglycerides often resulting from high dietary fats, is another important cause for pancreatitis ${ }^{57-59}$ and is present in many alcoholics ${ }^{60,61}$. Excessive alcohol consumption has been suggested to be associated with hypertriglyceridemia-induced pancreatitis ${ }^{62,63}$.

The risk of alcohol pancreatitis can also be altered by genetic modifiers. The CLDN2 (Clauding 2) gene encodes a tight junction protein-regulating cation and water transport of epithelial cells, and it is normally expressed in pancreatic duct cells but not acinar cells ${ }^{64,65}$. In a genome-wide study, a CLDN2 risk allele, which is associated with an abnormal expression of CLDN2 protein in pancreatic acinar cells, was identified as a risk factor that interacted with alcohol consumption to accelerate the progression of chronic pancreatitis ${ }^{66}$. In another genome-wide association study, an inversion of the CTRB1-CTRB2 (chymotrypsin B1 and B2) locus led to the imbalanced expression of CTRB1 and CTRB2 and an increased risk for both alcoholic CP and non-alcoholic CP 67.

Racial/ethnic differences are another susceptibility factor that can alter the risk of alcoholic pancreatitis. A population study using nationwide inpatient samples of the racially diverse US population between 1988 and 2004 demonstrated that Black people had the highest frequency of alcohol-related pancreatitis ${ }^{68}$. Another study using data collected by the North American Pancreatitis Study Group from 2000 to 2014 found that Black people were more likely to be diagnosed with $\mathrm{CP}$ than White people, likely because of alcohol consumption and smoking being more frequent in Black people ${ }^{69}$. In a number of studies conducted in the Asian population, a dose-response relationship between alcohol and pancreatitis was revealed ${ }^{70-72}$. The impact of ethnicity on the risk of alcoholic pancreatitis in these Asian studies was suggested to be related to the genetic polymorphism of alcohol metabolism enzymes; as genetic variant alleles of the 
aldehyde dehydrogenase-2 gene (ALDH2*2) and alcohol dehydrogenase-1B gene (ADH1B*2), which are associated with the accumulation of toxic acetaldehyde after alcohol drinking, were predominantly found in East Asians ${ }^{73-76}$.

\section{Animal and cell culture models for alcoholic pancreatitis}

Epidemiologic studies have indicated that alcohol can act as a mild initiator or a robust modifier to sensitize the pancreas to the insult of other risk factors during the development of pancreatitis. To understand the mechanisms underlying the pathogenesis of alcohol-related pancreatitis, many animal and cell culture models have been established. These experimental models have recapitulated the clinical features of alcohol-related pancreatitis, facilitated our understanding of the pathology, and provided opportunities to test potential therapeutic treatments for the disease.

Consistent with epidemiologic studies, alcohol alone, either by acute exposure ${ }^{77}$ or by chronic feeding ${ }^{78-80}$, is not sufficient to induce pancreatitis-like features in rodent models. Recent studies have used chronic exposure combined with binge drinking and showed that alcohol, when acting as both the initiation and susceptibility factor, can cause pancreatic injuries which mimic pancreatitis. Binge alcohol exposure by intragastric intubation for 10 consecutive days (5 $\mathrm{g} / \mathrm{kg} /$ day, $25 \%$ ethanol w/v) caused pancreatic edema, acinar cell death and moderate fibrosis in C57BL mice ${ }^{81}$. Mice receiving a liquid alcohol diet for two weeks followed by binge alcohol exposure by oral gavage for 3 days $(5 \mathrm{~g} / \mathrm{kg} / \mathrm{day}, 25 \%$ ethanol $\mathrm{w} / \mathrm{v})$ displayed more severe injuries and inflammation in the pancreas ${ }^{82}$. A 10-day feeding of a liquid alcohol diet plus a single binge ethanol exposure was found to lead to pancreatic edema and inflammation in C57BI/6 mice ${ }^{83,84}$. The chronic plus binge model may be of clinical relevance because it is similar to the drinking pattern of many alcoholic patients who have a history of chronic alcohol consumption and tend to have heavy episodic drinking ${ }^{85-87}$. In fact, the chronic plus binge exposure has also been used in animal models for alcoholic liver disease (ALD), as it has been shown to cause significant 
elevation of serum alanine aminotransferase (ALT) and aspartate aminotransferase (AST) levels and hepatic histological features, which bear a closer resemblance to the symptoms of early ALD patients, compared to chronic alcohol feeding or a single binge alone $83,88,89$

Alcohol can also act as a co-factor to sensitize the pancreas to the adverse effects of other susceptibility factors in the progression of pancreatitis. One physiologically relevant animal model for alcohol-related pancreatitis is the co-exposure of cholecystokinin (CCK) analogs and alcohol. CCK is an intestine hormone and is one of the most commonly used models to induce mild AP in rats ${ }^{90-93}$ and a more severe form in mice ${ }^{94-97}$ at a dose that is at least 10 times higher than the physiological condition. CCK analog-induced AP can recapitulate pathologic features of human AP caused by scorpion venom and cholinergic toxins ${ }^{98-101}$. The co-treatment of alcohol can either reduce the threshold concentration of CCK analogs that is required to elicit a pancreatitis response or intensify the pathologic response of the pancreas. Pandol et al. (1999) demonstrated that alcohol exposure sensitized rats to pancreatitis induced by CCK-8 at the physiological concentration, which by itself did not cause pancreatitis ${ }^{92}$. Quon et al. (1992) showed that chronic feeding of an alcohol diet exacerbated CCK analog caerulein-induced pancreatitis in rats, marked by greater increases in serum lipase level, interstitial edema and acinar vacuolization compared to that of animals treated with caerulein alone ${ }^{102}$. Repeated use of caerulein over time induced pathological features of the pancreas in rodents that mimicked human CP 103-105. Alcohol exposure accelerated the progression of caerulein-induced CP in rats ${ }^{105}$ and mice ${ }^{106}$.

Another clinically relevant animal model is lipopolysaccharides (LPS)-induced alcoholic pancreatitis in rodents ${ }^{107}$. LPS are endotoxins derived from gram negative bacteria in the gut, which can be released to the blood to cause LPS-associated toxicity ${ }^{108}$. There has been reported a higher plasma level of LPS in alcoholics ${ }^{109,110}$ and an association between plasma endotoxin concentrations and the severity of human AP ${ }^{111}$. In rat models, LPS and alcohol exposure have been shown to cause a more severe pancreatic injury than LPS alone ${ }^{107,112}$. Withdrawal of alcohol after manifestation of LPS-induced pancreatitis in rats resulted in the resolution of 
pancreatic lesions, including fibrosis and cell death, whereas continued alcohol administration aggravated the injury ${ }^{113}$. In a rat model of alcoholic AP, alcohol increased the expression of LPSinduced proinflammatory factors in acinar cells, including TNFa, IL-6, IL-10 and IL-18 ${ }^{114}$. The elevated expression of these inflammatory mediators was also observed in human AP and recurrent AP patient samples, suggesting an involvement of inflammation in alcoholic pancreatitis 114.

There are other susceptibility factors that have been identified in experimental models and have been shown to be associated with alcoholic pancreatitis. Hyperlipidemia and pancreatic duct obstruction, which cause minimal pancreatic damage individually, induced clinically relevant pancreatitis in rats when combined with alcohol feeding ${ }^{115}$. Genetic mutations, as exemplified by a pathogenic human p.N256K CPA1 (Carboxypeptidase A1) mutant when expressed in mice, caused protein misfolding, ER stress and progressive $\mathrm{CP}$, which was aggravated by alcohol exposure ${ }^{116}$. A severe pancreatitis phenotype manifested in knock-out mice for nuclear factor erythroid 2 like 2 (NRF2), a regulator of cellular antioxidant response and ethanol metabolism, was worsened by acute binge alcohol exposure, suggesting an involvement of oxidative stress or ethanol metabolites in alcoholic pancreatitis ${ }^{117}$.

In addition to animal models, many in vitro models have been proposed to address the mechanisms underlying the pathology of alcoholic pancreatitis. The exocrine compartment of the pancreas is mainly composed of acinar and ductal cells. The pancreatic acinar cells are the functional unit of exocrine pancreas, constituting about $80 \%$ of the pancreas. Their function is to synthesize, store and secrete digestive enzymes. Acinar cells are believed by many to be the initiation site of pancreatic injury, as molecular and cellular events linked to acinar cell dysfunction have been shown to occur early in pancreatitis ${ }^{118-121}$. Similar to animal models, pancreatic acinar cells when treated by alcohol alone, but not in combination with other stressors in vitro, appeared to display minimal damages. Chronic alcohol exposure at a clinically relevant concentration (50 $\mathrm{mM}$ equivalent to $230 \mathrm{mg} / \mathrm{dl}, 96$ hours) reduced the cellular uptake of thiamine pyrophosphate 
(TPP) in rat primary acini, rat pancreatic AR42J acinar cells ${ }^{122}$ and mouse pancreatic 266-6 acinar cells ${ }^{123}$, indicative of alcohol's damaging effects on pancreatic thiamine-dependent functions ${ }^{124-}$ 126. Alcohol exposure at the concentrations from $200-800 \mathrm{mg} / \mathrm{dl}$ for 6 hours caused mild apoptosis of AR42J cells and a minimal effect on the activity of lipase or amylase ${ }^{127}$. Lugea et al. (2017) showed alcohol treatment $(50 \mathrm{mM}$ equivalent to $230 \mathrm{mg} / \mathrm{dl}$ ) for 4 days decreased the viability of AR42J cells only in combination with cigarette smoke extracts but not by itself ${ }^{128}$. In CCK-8-stimulated primary mouse pancreatic acini, alcohol treatment altered $\mathrm{Ca}^{2+}$ homeostasis ${ }^{129}$, increased reactive oxygen species (ROS) production ${ }^{130}$ and reduced CCK-8-evoked amylase secretion ${ }^{131}$. In rat pancreatic acini, alcohol treatment exacerbated the pathological intra-acinar protease activation induced by muscarinic agonist carbachol ${ }^{132}$.

Pancreatic ductal cells, which are responsible for transporting the acini-produced digestive enzymes into the duodenum and secreting bicarbonate-rich fluid to neutralize stomach acid, have also been proposed to be involved in the pathology of pancreatitis ${ }^{133-135}$. Alteration of ductal cell function may cause insufficient transportation or precipitation of digestive enzymes in the ducal lumen, which may lead to obstruction and damage. Sarles et al. (1965) showed the formation of mucoprotein plugs in the pancreatic ducts was an early lesion in the pathology of alcohol-induced chronic calcifying pancreatitis ${ }^{136}$. Mutations in the cystic fibrosis transmembrane conductance regulator (CFTR), an ion channel protein highly expressed in pancreatic duct cells, was found to be associated with $\mathrm{CP}^{137}$. Maleth et al. (2015) showed ethanol exposure reduced the expression of CFTR, and disrupted the folding of CFTR at endoplasmic reticulum (ER) in a number of human pancreatic cell lines and pancreatic tissues of mice and guinea pigs ${ }^{138}$. In addition, CFTR knockout mice developed more severe pancreatitis when given ethanol than $W T$ control mice ${ }^{138}$.

\section{Endoplasmic reticulum (ER) stress and unfolded protein response (UPR) in alcohol-related pancreatitis}


The endoplasmic reticulum (ER) is an intracellular compartment that plays a major role in protein folding and processing, and calcium storage and release, and it also serves as the first step of secretory pathway followed by the Golgi apparatus ${ }^{139,140}$. Cellular stress factors, such as deficiencies in protein processing, disturbance in calcium level or the redox state, result in the accumulation of unfolded/misfolded proteins within the ER, which is known as ER stress and triggers an adaptive response known as unfolded protein response (UPR). UPR can either resolve the ER stress when the stress is reversible or cause cell death when the stress is irreversible. The pancreatic acinar cells are particularly vulnerable to ER stress because of their primary function, which is to synthesize and secrete digestive enzymes for food digestion, largely depending on ER functionality. ER stress and UPR signaling have been shown to be activated in a variety of experimental models of pancreatitis, including arginine-induced AP ${ }^{141}$, caeruleinand taurocholate-induced AP ${ }^{142}$, and CP induced by repeated episodes of caerulein ${ }^{143}$. The occurrence of ER stress and the activation of UPR signaling during the initiation of pancreatitis suggest that ER stress plays an important role in the development of pancreatitis. The involvement of ER stress in pancreatitis is also shown in the human studies as an autosomal dominant mutation (p. R116C) in human cationic trypsinogen gene, which is associated with hereditary pancreatitis, induces the accumulation of misfolded trypsinogen, ER stress and UPR signaling ${ }^{144-147}$. Although alcohol exposure only caused minimal pancreatic injury in animals with intact UPR functions ${ }^{128,148}$, loss of function of a UPR regulator X-box binding protein 1 (Xbp1) resulted in altered ER structure, acinar cell damage and pancreatitis-like features in alcoholexposed animals, pointing to a critical protective role of UPR in alcoholic pancreatitis ${ }^{80,149}$.

UPR signaling is the major cellular response induced by ER stress, and it consists of three distinct but also interconnected intracellular signal transduction pathways (Fig. 1). These pathways are initiated by three ER-resident transmembrane sensor proteins: inositol-requiring kinase 1 (IRE1 both $\alpha$ and $\beta$ isoforms), protein kinase-like ER kinase (PERK) and activating transcription factor 6 (ATF6 both $\alpha$ and $\beta$ isoforms $)^{150-152}$. These transmembrane sensor proteins 
have an ER luminal sensor domain and a cytosolic effector domain, thereby transmitting the protein folding status inside ER to other cellular compartments via intracellular signaling pathways. In non-stressed cells, all the sensor proteins remain inactive by binding to an ER chaperone 78kDa glucose-regulated protein (GRP78) through their N-terminus ${ }^{153,154}$. Under the conditions of ER stress, GRP78 dissociates from these sensor proteins to initiate their activation 153,154 . The activated UPR signaling pathways attempt to stop improper translation, facilitate protein folding and therefore maintain ER homeostasis. However, if the ER stress is not resolved, UPR triggers cell death ${ }^{155-157}$.

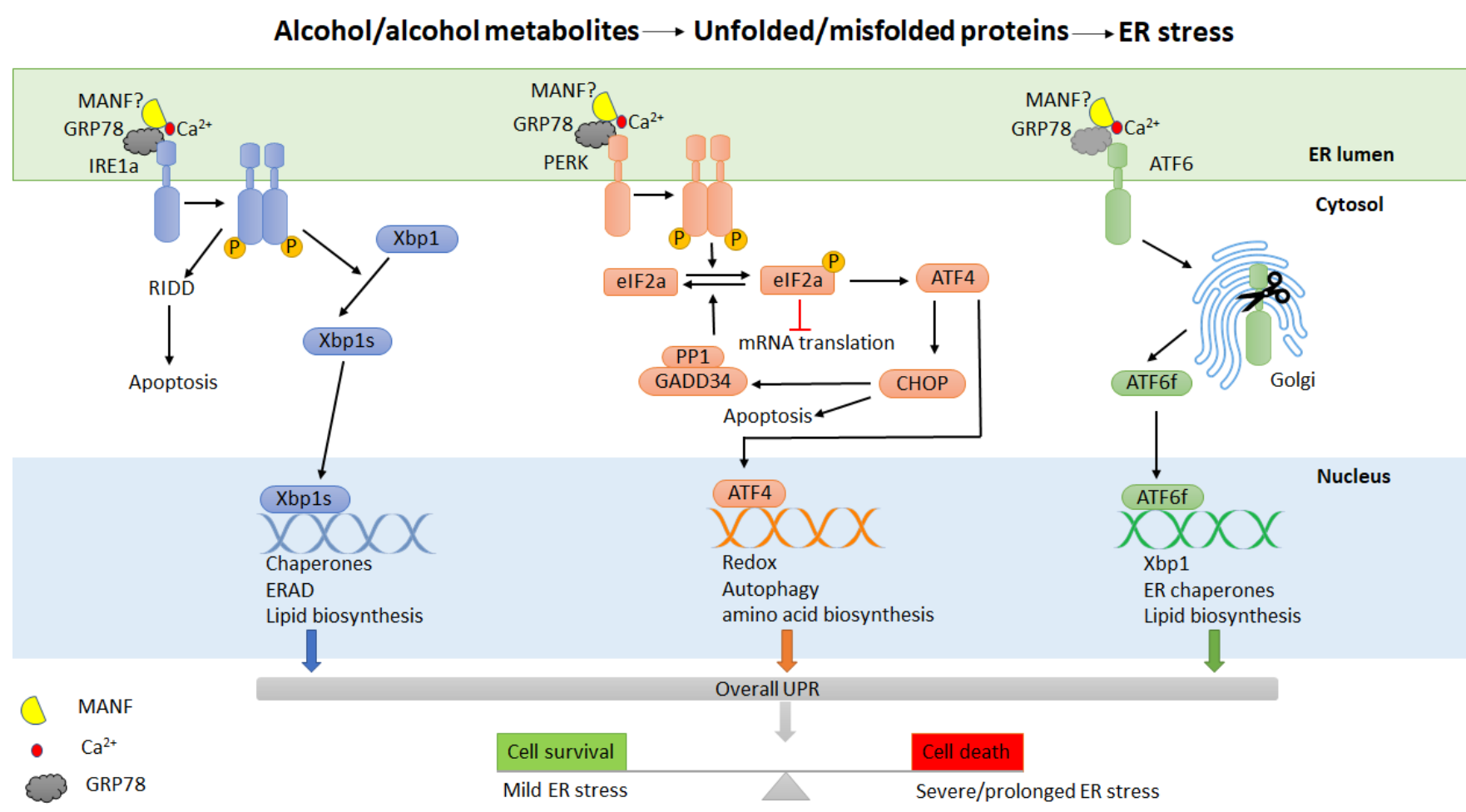

Figure 1: Alcohol exposure and ER stress. Alcohol and its metabolites may cause ER stress and induce a cellular adaptive response known as the unfolded protein response (UPR) in the pancreas. UPR is controlled by three transmembrane sensor proteins: inositol-requiring enzyme

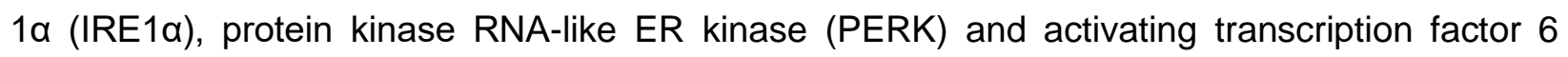
(ATF6). Under non-stressed conditions, these sensor proteins bind to GPR78 and possibly MANF in a calcium-dependent manner. Alcohol exposure results in the accumulation of unfolded or 
misfolded proteins in the ER, which in turn causes the release of GRP78/MANF to activate UPR. The activation of UPR regulates transcriptional and translational programs to either restore protein folding, promote protein degradation, or induce cell death.

IRE1 is the most evolutionarily conserved ER stress sensor protein with dual protein kinase and RNase activities ${ }^{158-160}$. At the onset of ER stress, dissociation of GRP78 activates IRE1, which involves dimerization and trans-autophosphorylation of IRE1 kinase domains, followed by the activation of the RNase domain in the cytosol. Activated IRE1 regulates the splicing of transcription factor $\mathrm{X}$ box-binding protein 1 (XBP1) to generate a more stable and active form known as Xbp1s ${ }^{161}$. XBP1s translocates to the nucleus and mediates the expression of a group of target genes in protein folding, ER-associated degradation (ERAD) and phospholipid synthesis, thereby acting as an adaptive response that promotes the folding capacity of ER to alleviate ER stress ${ }^{151,162,163}$. In addition, activated IRE1 also regulates a subset of RNAs leading to cell death through a process known as IRE1-dependent RNA decay (RIDD) ${ }^{164-166}$. Both IRE1 and XBP1 are essential in secretory cells, including pancreatic acinar cells 167,168 . IRE1 $\alpha$ conditional knock-out mice have lower pancreas mass and abnormally structured pancreatic acinar cells but showed no difference in the level of amylase expression and secretion ${ }^{168}$. Conditional disruption of Xbp1 caused decreased production of digestive enzymes and zymogen granules, altered ER structure and extensive apoptosis in mouse pancreatic acinar cells ${ }^{167,}{ }^{169}$. In a mouse model for alcoholic pancreatitis, alcohol exposure activated IRE1/Xbp1-mediated UPR and only caused minimal pancreas damage in $W T$ mice, while $X b p 1^{+/-}$mice displayed significant acini necrosis, inflammation and reduction in zymogen granules and amylase levels, indicative of a protective role of XBP1 against alcohol-induced damages in the exocrine pancreas ${ }^{170}$.

PERK is an ER-resident kinase that is composed of cytosolic and kinase domains ${ }^{171,172 .}$ Similar to IRE1, the activation of PERK also involves dimerization and trans-autophosphorylation. Activated PERK phosphorylates the $\alpha$-subunit of the translation initiation factor elF2 (eukaryotic 
translation initiation factor-2) to reduce global protein synthesis ${ }^{171-173}$. This reduces the amount of protein entering the ER and alleviates ER stress. The phosphorylation of elF2 $\alpha$ by PERK also results in the selective translation of activating transcription factor 4 (ATF4), which regulates the expression of genes involved in protein folding, amino acid metabolism and autophagy ${ }^{174,}{ }^{175}$. ATF4 also modulates the expression of proapoptotic molecules, including the transcription factor C/EBP homologous protein (CHOP) and growth arrest and DNA damage-inducible protein (GADD34) ${ }^{176-178}$. GADD34 plays a role in a feedback loop to dephosphorylate elF2 $\alpha$ by interacting with protein phosphatase 1 (PP1), which reverses translational inhibition and induces cell death ${ }^{156,179}$. PERK is highly expressed in a number of tissues, including the exocrine and endocrine pancreas ${ }^{180}$. PERK knock-out $\left(\right.$ Perk $\left.^{-/}\right)$mice displayed reduced expression of major digestive enzymes, abnormal ER morphology and apoptosis of acinar cells and increased number of stellate cells ${ }^{180,181}$. The loss of acinar cells and proliferative response of stellate cells in Perk ${ }^{1-}$ mice are also often observed in patients with chronic alcoholic pancreatitis ${ }^{182}$. In addition, the pancreatic acinar cell-specific Perk knock-out mice exhibit AP-like features, such as cell death and the inflammatory response ${ }^{183}$.

ATF6 is an ER-localized membrane-bound transcription factor. Under ER stress, ATF6 is translocated to Golgi and cleaved proteolytically to release the transcriptionally active N-terminal domain, which enters the nucleus and activates the transcription of several UPR-related genes, including GRP78, Xbp1 and CHOP 161, 184, 185. ATF6 has been shown to play an essential role in modulating the ER function particularly in chronic stress ${ }^{186,187}$. High expression levels of ATF6, CHOP and Xbp1 have been observed in human CP pancreatic tissues, together with histological and cellular characteristics of CP, suggesting that ATF6/Xbp1/CHOP signaling may be involved in the development of $\mathrm{CP}{ }^{188}$. In a CP model induced by caerulein injection in PRSS1 transgenic mice, ATF6 was shown to regulate the apoptosis of pancreatic acinar cells and the progression of CP ${ }^{188}$. 
The timing and intensity of the activation of the three UPR signaling pathways are different in response to a particular ER stressor $157,189,190$. Alcohol exposure can cause ER stress and induce UPR in pancreas of animals and cultured pancreatic cells (Fig. 1). Depending on the experimental models and the paradigm of alcohol exposure, the three pathways of UPR are differentially impacted. For example, acute alcohol exposure increased UPR components, including GRP78, p-IRE1a, XBP1 and CHOP in human pancreatic acinar cells (hPACs) in a concentration-dependent manner ${ }^{191}$. Prolonged exposure of alcohol increased GRP78 and CHOP expression in AR42J cells ${ }^{191}$. In AR42J cells and mouse primary acini, the co-treatment of cigarette smoke extract and alcohol induced cell death, which was accompanied by PERK activation and increased expression of CHOP ${ }^{128}$. In animal models, it appears that a single episode of alcohol exposure is not sufficient to induce pancreatitis. Therefore, repeated exposure by binge drinking or combined binge and chronic alcohol exposure have been used and shown to cause pancreatitis. For example, repeated alcohol binge exposure ( $25 \%$ ethanol w/v, 5 $\mathrm{g} / \mathrm{kg} /$ day for 10 days by oral gavage) resulted in pancreatitis-like features in male C57BL6 mice, including inflammation, increased UPR markers (ATF6, GRP78, p-PERK, p-elF2 $\alpha$ and CHOP), elevated expression of amylase and apoptosis ${ }^{192}$. A paradigm of chronic $(5 \%$ ethanol diet for 2 weeks) plus binge alcohol exposure ( $5 \mathrm{~g} / \mathrm{kg}, 25 \%$ ethanol w/v for 3 days) induced the expression of p-elF2 $\alpha$, XBP-1, CHOP, ATF-6 and PERK; amylase secretion; pancreatic inflammation and apoptotic cell death in the mouse pancreas ${ }^{82}$.

\section{Potential treatment of alcoholic pancreatitis by targeting ER stress and UPR}

Based on the aforementioned evidence and our own findings, we hypothesize that ER stress plays an important role in the etiology of alcoholic pancreatitis (Fig. 2). Although alcohol exposure alone may not directly result in pancreatitis, it works together with other pathological conditions, such as genetic alterations and cellular stressors, to initiate the pathogenesis of pancreatitis. Alcohol may promote pancreatitis through the following mechanisms: 1) Since 
alcohol exposure causes ER stress in the pancreas, pre-existing imbalance of ER homeostasis or ER dysfunction may exacerbate alcohol-induced ER stress, which is beyond UPR's ability to restore and results in severe pancreatic damages and pancreatitis; 2) The genetic mutations or protein alterations in key components of UPR or ER-associated degradation (ERAD) pathways may already impair pancreatic cells' ability to alleviate ER stress. Upon alcohol exposure, sustained and severe ER stress results in cell death, inflammation, and other pancreatic damages; 3) Reversely, alcohol exposure, especially chronic and heavy alcohol consumption, may disrupt ER homeostasis or impair UPR or ERAD systems, which sensitizes pancreatic cells to other genetic or environmental stressors. As a result, alcohol abusers are more susceptible to etiological initiators of pancreatitis.
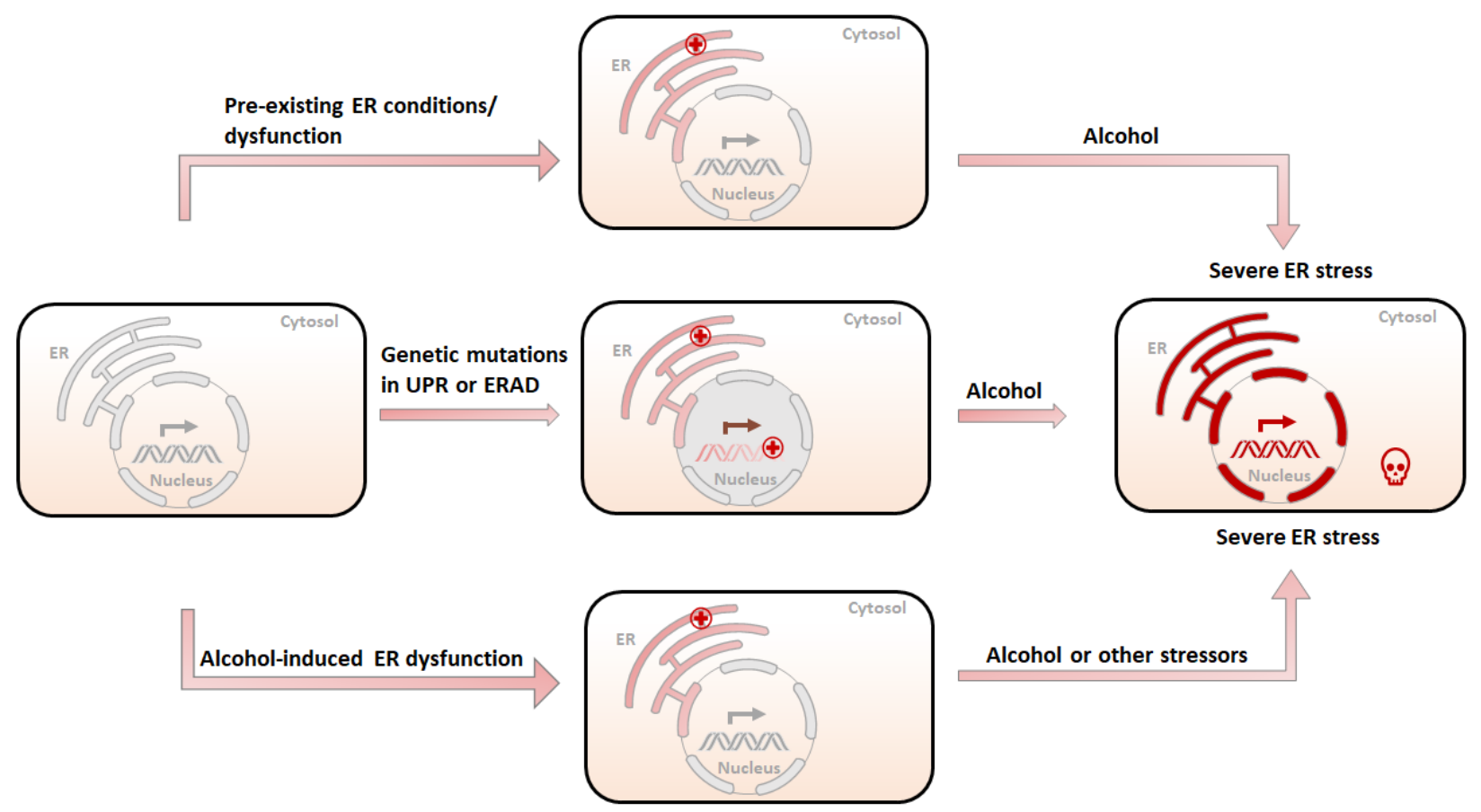

Alcohol or other stressors

Figure 2: Possible etiology of alcohol-related pancreatitis. 1) A pre-existing ER condition resulting from stressors other than alcohol (tobacco, high-fat diet etc.) is further exacerbated by alcohol exposure, which causes irreversible damage of the ER and subsequent cell death. 2) Genetic mutations in UPR or ERAD compromise the ability of ER to dealing with unfolded/misfolded proteins, and therefore sensitize the ER to alcohol-induced damages, which 
leads to severe ER stress and pancreatic damages. 3) Pre-exposure to alcohol compromises the ability of ER to maintain its homeostasis and makes the ER to be susceptible to subsequent alcohol exposure or other ER stressors, resulting in severe pancreatic damages.

Since ER stress plays an important role in the pathogenesis of alcoholic pancreatitis, pharmacological modulations that target ER stress may be an effective strategy for therapy (Fig. 3). Small molecules that can regulate ER homeostasis and the UPR/ERAD system have drawn great attention for this purpose. In addition, repurposing existing drugs in a new pharmacology class is the safest and cheapest option for disease intervention. Although there are currently no drugs approved by the FDA for alcoholic pancreatitis, a number of FDA-licensed drugs that exert therapeutic effects through controlling ER homeostasis and mitigating ER stress can be repurposed and tested for the disease ${ }^{193-195}$.

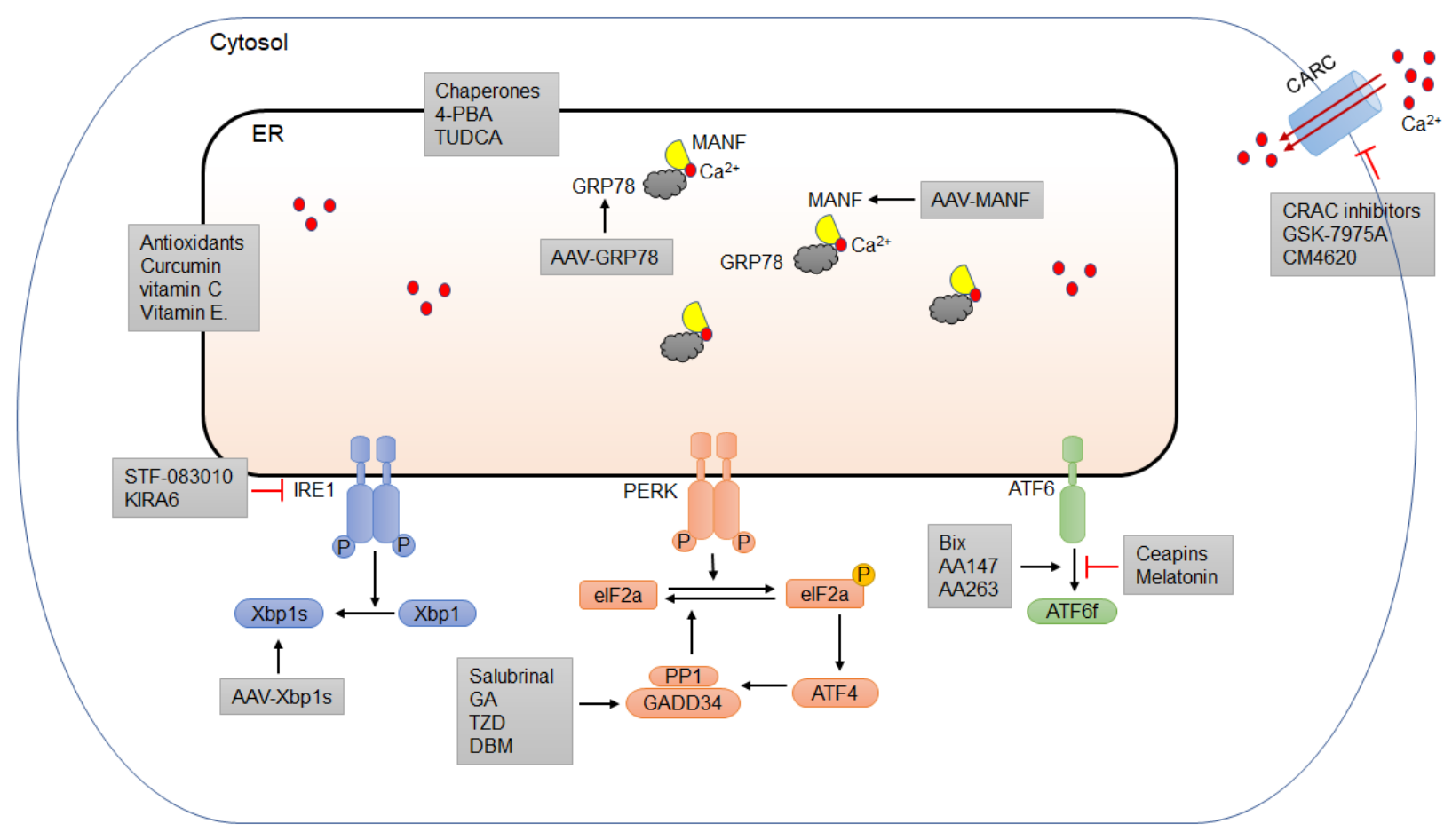

Figure 3: Potential pharmacological intervention for alcoholic pancreatitis targeting

ER homeostasis. It is of great potential to identify specific molecules or strategies targeting ER 
stress and different UPR components. One of the most direct pharmacological approaches to alleviate ER stress is to use chemical chaperones, such as 4-PBA and TUDCA to facilitate protein folding and alleviate ER stress. Another effective approach is to use specific small molecule inhibitors or activators to modulate different UPR components. Among the three arms of UPR, PERK/elF2 $\alpha$ is the most important in controlling the protein translation and the transition to apoptotic cell death and has been drawn greater attention. A number of small molecules targeting this pathway have been shown to have protective effects against ER stress-induced damages. Recently, several FDA-approved drugs that can affect some UPR components exhibit potential benefits to alleviate ER stress and reduce pancreatic damages. One of potential mechanisms for alcohol-induced ER stress is the perturbation of ER calcium homeostasis. Small molecules targeting calcium channels have therapeutic potential for ER stress-induced pancreatic damages. Antioxidants, such as vitamin $\mathrm{C}$ and vitamin $\mathrm{E}$ have been shown to alleviate ER stress and may be useful to treat alcoholic pancreatitis. Gene therapy using recombinant viruses, such as Adenoassociated viruses (AAVs) is becoming an attractive strategy to deliver active UPR components to specific tissues to mitigate ER stress. AAV delivery of several key UPR proteins, such as GRP78 and MANF demonstrates promising benefits to treat ER stress-related tissue damages.

One of the most direct pharmacological approaches to alleviate ER stress is to use small molecules that function as chemical chaperones to facilitate protein folding ${ }^{196}$. There are several chemical chaperones, including FDA-licensed drugs such as sodium phenylbutyrate (4-PBA) and ursodeoxycholic acid (UDCA) that can be readily repurposed for the treatment of alcoholic pancreatitis (Fig. 3). 4-PBA has been approved by the FDA for the treatment of patients with urea cycle disorders by acting as an ammonia scavenger ${ }^{197,198 .}$ 4-PBA can also act as an ER stress inhibitor and has been suggested to modulate the restoration of ER homeostasis in many pathological conditions ${ }^{8,199-201}$. Hong et al. (2018) showed that 4-PBA attenuated tissue injury which was accompanied by reduction of the expression of ER stress markers, inflammatory 
response and cell death in sodium taurocholate-induced AP in rats ${ }^{202}$. In addition, the trypsin activation, UPR signaling and apoptosis of rat pancreatic acini induced by the supraphysiological cholecystokinin were suppressed by 4-PBA ${ }^{203}$. UDCA, also known as ursodiol, is a bile acid that has been approved by the FDA as a therapy for gallstone and liver diseases ${ }^{204-206}$. UDCA appears to have beneficial effects in treating idiopathic pancreatitis ${ }^{207,208}$. However, due to its poor absorption, people have recently shifted their attention to tauroursodeoxycholic acid (TUDCA), a more readily absorbed form that also has the same cytoprotective properties as UDCA. TUDCA is an ER chaperone that has been shown to attenuate ER stress and reduce intracellular trypsin activation, edema formation and the inflammatory reaction of pancreatic tissue in a caerulein-induced AP rat model ${ }^{209}$. Pretreatment of TUDCA suppressed ER stress responses and alleviated ER stress-associated apoptosis in cholecystokinin (CCK-8)-stimulated rat pancreatic acini ${ }^{210}$.

Another approach to relieve ER stress is to manipulate the UPR pathways by using small molecule inhibitors or repurposed FDA-licensed drugs (Fig. 3). Among the three arms of UPR, PERK/elF2 $\alpha$ is the most important in controlling the protein translation and the transition to apoptotic cell death ${ }^{211,212}$. Chemicals that can reduce the protein translation by modulating the PERK/elF2 $\alpha$ pathway are of therapeutic potential. Salubrinal is a selective inhibitor of elF2 $\alpha$ phosphatases that was initially identified in a screen for small molecules that protect the rat pheochromocytoma cell line PC12 from ER stress-induced apoptosis ${ }^{213}$. A recent study showed that salubrinal ameliorated pancreatic injuries by inhibiting the dephosphorylation of elF2 $\alpha$ in caerulein/LPS-induced-AP in mice ${ }^{214}$. However, increased elF2 $\alpha$ phosphorylation by salubrinal was proapoptotic in pancreatic beta cells and exacerbated the toxicity of ER stressors such as the free fatty acids oleate and palmitate, which makes salubrinal an unfavorable drug candidate to treat pancreatic disorders like alcoholic pancreatitis ${ }^{215}$. There are several FDA-approved drugs, including guanabenz acetate (GA), trazodone (TZD) and dibenzoylmethane (DBM), that have been shown to target different components of the PERK/elF2 $\alpha$ pathway and can mitigate ER 
stress. GA is an FDA-approved anti-hypertensive drug. Trazodone is a licensed anti-depressant. DBM is a curcumin analogue that has anti-cancer properties ${ }^{216}$. These drugs have outstanding pharmacokinetics and are considered safe. GA has been shown to attenuate ER stress and play a beneficial role in several models of neurological diseases, including amyotrophic lateral sclerosis (ALS), oculopharyngeal muscular dystrophy (OPMD), hereditary spastic paraplegias (HSPs) and spinal cord injury (SCI) ${ }^{217-220}$. However, It has also been reported that GA sensitizes pancreatic $\beta$ cells to fatty acid-induced ER stress and apoptosis through PERK/elF2 $\alpha$ signaling 221. TZD and DBM have been shown to provide neuroprotection and cognitive improvement by reducing protein accumulation in models of prion disease and frontotemporal dementia, with no overall toxicity ${ }^{193}$. In a small-molecule screening for the treatment of diabetes, TZD has been identified as a stimulator for the proliferation of pancreatic $\beta$ cells ${ }^{222}$. Despite its short-term benefit in alcohol withdrawal syndrome ${ }^{223,224}$, TZD may increase alcohol consumption and worsen the drinking outcomes when stopped ${ }^{225}$. The effects of these drugs in alcoholic pancreatitis, therefore, need to be evaluated in the preclinical models first.

IRE1 $\alpha /$ XBP1 signaling pathway is another UPR arm that has been implicated in experimental models for alcohol-induced pancreatitis ${ }^{170,226}$. There are two classes of small molecule inhibitors for IRE1 $\alpha$ that have been developed to modulate IRE1 $\alpha / X B P 1$ signaling in ER stress-mediated diseases ${ }^{227}$. The first group binds to the RNase domain of IRE1a and inhibits its RNase activity. These inhibitors, including toyocamycin, 3-Ethoxy-5,6-dibromosalicylaldehyde, STF-083010 and 2-Hydroxy-1-naphthaldehyde, have been shown to induce apoptosis in a number of pancreatic tumor cell lines ${ }^{228}$. Of note, STF-083010 has been shown to protect mouse pancreatic 266-6 acinar cells from alcohol-induced cytotoxicity in vitro ${ }^{229}$ (Fig. 3). Another inhibitor which also belongs to the first group, MKC-3946, was shown to cause cell death in rat pancreatic AR42J acinar cells, primary mouse and human acinar cells in vitro ${ }^{128}$. The second class of IRE1a inhibitors targets its kinase domain to exert allosteric control of IRE1a RNase activity. One of the IRE1a kinase inhibitors, kinase-Inhibiting RNase-Attenuator 6 (KIRA6), was 
recently developed and shown to promote the viability and function of the pancreatic beta cells in ER-stress-induced diabetic mice ${ }^{230}$ (Fig. 3). Given the opposite effects that IRE1 inhibitors exert on cellular survival and function in different disease models, one should take precautions when repurposing them for alcoholic pancreatitis and examine their effects in experimental models on a case-by-case basis.

The modulators of ATF6 are few due to the unavailability of the crystal structure of the ATF6 protein, which presents challenges for the identification of druggable binding sites ${ }^{231}$. Using a cell-based assay, Gallagher identified ceapins as a class of ATF6- specific inhibitors by preventing the translocation of ATF6 from the ER to the Golgi upon ER stress ${ }^{232}$. The effect of ceapins on the viability or function of pancreatic acinar cells, however, has not been tested in pancreatic inflammatory contexts. Melatonin is another ATF6 selective inhibitor. In a rat model for intracerebral hemorrhage, melatonin has been shown to exert neuroprotective effects via the suppression of the ATF6 pathway ${ }^{233}$. Melatonin was also shown to attenuate inflammation in LPS-induced AP in AR42J cells and in taurocholate-induced AP in rats 234,235 . Interestingly, pharmacologic ATF6 activation has also been shown to be protective in many diseases, including ischemic heart disease, and diabetes and neurodegenerative disorders ${ }^{236-240}$. Through reporterbased assays, Bix, compound 147 (AA 147) and 263 (AA 263) have been identified and specifically activate the ATF6 arm of the UPR ${ }^{241-243}$. Bix has been shown to exert beneficial effects in experimental models for multiple disease conditions, such as stroke and kidney injury 243, 244. In a mouse model of ischemic heart disease, AA 147 was shown to exert a protective effect in multiple tissues, including heart, brain, kidney and liver ${ }^{236}$. These selective ATF6activating compounds are ready to be tested in experimental models for alcoholic pancreatitis.

ER stress can also result from perturbations of calcium level, as ER resident chaperones and folding enzymes have calcium-binding sites and calcium-dependent functions ${ }^{245}$. Alcohol and its metabolites can deplete calcium level in the ER by activating inositol trisphosphate receptors, calcium release channels located in the ER, to induce ER stress and pancreatic acinar 
cell death and inflammation in experimental models for alcohol-related pancreatitis ${ }^{246,247}$. The release of calcium from the ER would elevate the calcium level in the cytosol, which in turn would activate calcium release-activated calcium (CRAC) channels on the plasma membrane to promote the uptake of extracellular calcium, which would further increase the concentration of intracellular calcium. The pathological elevation of cytosolic calcium and the activated CRAC can further augment cell death and inflammation in the pancreas ${ }^{133,248-251}$. Small molecules targeting calcium channels have therapeutic potential for ER stress-related disorders like alcoholic pancreatitis. For example, two small molecule inhibitors of CRAC channels (Orai1), GSK-7975A and CM_128 (also known as CM4620), have been shown to inhibit the activation of ORAI1 and prevent cell death and inflammation in thapsigargin-treated human pancreatic acinar cells and mouse models of AP induced by alcohol and palmitoleic acid ${ }^{249}$ (Fig. 3). In addition to acinar cells, CM4620 has also been shown to target pancreatic stellate cells and immune cells, block calcium entry and reduce pancreatitis features and severity in experimental AP models ${ }^{252}$. In fact, CM4620 has reached Phase I clinical trials for treating AP due to its adequate specificity and low toxicity ${ }^{253}$.

Alcohol can also cause ER stress and pancreatic acinar cell injury by altering the redox state of the ER. Many experimental models of alcohol-related pancreatitis have shown that alcohol exposure leads to oxidative stress in the ER through its oxidative metabolites/by-products or the generation of ROS $82,128,192,254$. Curcumin is a natural antioxidant extracted from turmeric that has been shown to protect the pancreas by lowering the severity and inflammatory response in a rat pancreatitis model induced by alcohol and a low-dose of CCK ${ }^{255}$ and non-alcoholic pancreatitis models ${ }^{255-257}$. Because of its safeness, tolerability and low toxicity, curcumin has been tested in clinical trials for numerous diseases ${ }^{258}$, both alone or in combination with other reagents, and it has been shown to be protective against alcohol intoxication ${ }^{259}$ and pancreatic cancer ${ }^{260-262}$. Therefore, curcumin is a promising candidate for the treatment of alcoholic pancreatitis. Other therapeutical antioxidant candidates are vitamins that have antioxidant 
properties, such as vitamin C and E. Both vitamins are significantly low in the dietary intakes of patients with idiopathic CP ${ }^{263}$ or low in the blood of patients with alcoholic AP ${ }^{264}$ or CP ${ }^{265}$. Supplementation of vitamin $\mathrm{C}$ or vitamin $\mathrm{E}$ have been shown to exert anti-inflammatory and other beneficial effects in AP patients ${ }^{266}$ and in a rat model of alcoholic CP ${ }^{267 .}$

Gene therapy using recombinant viruses is becoming an attractive strategy to deliver active UPR components to specific tissues. This method avoids the pleiotropic effects of systemic and chronic administration of ER stress-targeting compounds. Adeno-associated viruses (AAVs) are the current choice to deliver therapeutic genes because of their safety profile demonstrated in pilot clinical trials ${ }^{268}$. GRP78 is an important ER chaperone and participates in the regulation of all three arms of UPR signaling ${ }^{269}$. Enhanced GRP78 expression can alleviate ER stress in experimental models for a variety of disorders ${ }^{270}$. For example, AAV-mediated gene transfer of GRP78 ameliorated retinal cellular injury by mitigating ER stress in mice ${ }^{271}$, rats ${ }^{272}$ and human retinal epithelium cells ${ }^{273}$. In a rat model of Parkinson's disease, overexpression of GRP78 by recombinant AAV attenuated ER stress, promoted the survival of nigral dopamine (DA) neurons and restored behavioral deficits ${ }^{274}$. Over-production of GRP78 driven by a rat insulin promoter in pancreatic beta cells provided protection against high-fat-induced ER stress and diabetes in mice ${ }^{275}$. In a caerulein-induced AP model, Grp78 ${ }^{+/}$mice displayed greater pathological alterations, including morphological change, cell necrosis, edema and inflammation, when compared to wild-type mice, suggesting a protective role of GRP78 in AP ${ }^{276}$. Therefore, one may take GRP78 into consideration as a potential therapeutic target in alcoholic pancreatitis, and AAVmediated delivery of GRP78 may be readily tested in experimental models.

The downstream transcription programs of the three UPR signaling pathways are mediated by transcription factors XBP1 (IRE1 pathway), ATF4 (PERK pathway) and ATF6 (ATF6 pathway), either individually or co-operatively. Gene delivery of those transcription factors may also be a potential strategy to optimize the beneficial effects of certain pathways in different diseases. Overexpression of XBP1 in the nervous system of adult animals by viral-based delivery 
has been shown to exert protective effects in a mouse model for Huntington's disease (HD) ${ }^{277}$, spinal cord injury ${ }^{278}$ and PD ${ }^{279,280}$. More recently, co-expression of XBP1 and ATF6 in a fusion protein by AAV-based delivery showed a more potent effect in neuroprotection and antiaggregation of mis-folded proteins than XBP1 or ATF6 alone in preclinical models for PD and HD, suggesting a cooperative action of XBP1 and ATF6 in enhancing the folding capacity of the ER and promoting cell survival under disease settings ${ }^{281}$. Overexpression of XBP1 by AAV-mediated delivery may be a promising therapeutic strategy readily tested in alcoholic pancreatitis because XBP1 has been implicated to have a beneficial role in alcohol-induced pancreatic damages in an experimental model for alcohol-related pancreatitis ${ }^{80}$. However, ATF6 has been shown to play a detrimental role in a mouse model for severe $A P^{282}$ and $C P^{188}$. Therefore, one should remain cautious when testing the effects of its overexpression in alcoholic pancreatitis. In contrast to the beneficial effects of overexpression of ATF6 and XBP1 in neurodegenerative disorders, AAVmediated overexpression of ATF4 has been shown to have deleterious effects in the brain of animal models for PD and caused behavioral deficits when compared to the control ${ }^{283}$. Excessive expression of ATF4 by AAV-mediated delivery resulted in cell death associated with ER stress in mouse models for progressive retinal degeneration ${ }^{284}$. A more recent study showed that ATF4 contributed to the pathogenesis of AP in caerulein-induced AP mouse models ${ }^{285}$. Therefore, AAV-mediated delivery of ATF4 seems to be unlikely to exert therapeutic benefits to the alcoholinduced pathology in the pancreas.

Another molecular target of interest in the treatment of alcoholic pancreatitis is mesencephalic astrocyte-derived neurotrophic factor (MANF). MANF is an ER stress-inducible secretory protein expressed in many human and mouse tissues, with a particularly high expression level in secretory tissues such as the pancreas ${ }^{286,287}$. MANF is activated by alcohol exposure and plays a protective role by alleviating alcohol-induced ER stress in the brain and in cultured acinar cells ${ }^{199,229,288}$ (Fig. 3). The cytoprotective role of MANF in the pancreas has been demonstrated by increased apoptosis and reduced proliferation of pancreatic beta cells and an 
insulin-deficient phenotype in pancreatic MANF knockout mice ${ }^{289,290}$. In humans, MANF has also

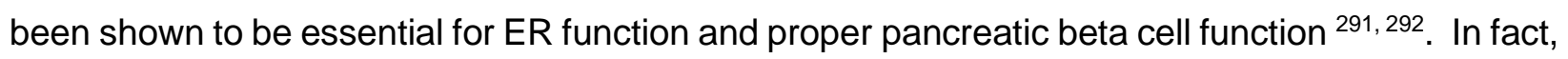
MANF has been proposed to serve as a diagnostic biomarker for children with type I diabetes, given the elevated level of MANF found in the serum of type I diabetic children ${ }^{293}$. In contrast to the role of MANF in the endocrine function of the pancreas which has been well characterized, the role of MANF in the exocrine compartment of pancreas has not drawn much attention until very recently. Using an in vitro model, we showed an siRNA knockdown of MANF exacerbated alcohol-induced damages in mouse pancreatic 266-6 acinar cells; whereas addition of recombinant human MANF or overexpression of MANF by adenovirus ameliorated alcoholinduced ER stress and cellular injury ${ }^{229}$. While this finding may imply a beneficial role for MANF in alcoholic pancreatitis, further studies of measuring the effect of gain- or loss-of-function of MANF on pancreatitis features in animal alcoholic pancreatitis are necessary. Delivery of the MANF gene to the brain using AAV protected neurons against ischemic injury in animal models 294-298. Therefore, it is of interest to determine whether AAV delivery of the MANF gene to the pancreas can exert protective effects against alcohol-induced damages. In addition, the serum level of MANF in patients with alcoholic pancreatitis is also worth investigating to determine if MANF can be a biomarker for alcoholic pancreatitis.

\section{Conclusions}

Alcoholic pancreatitis is a serious medical concern worldwide and remains to be one of the common causes of pancreatic disease. However, there are no FDA-approved drugs or treatments available for the disease. ER stress has been shown to play a critical role in the pathogenesis and progression of alcoholic pancreatitis. Approaches targeting ER stress may open a new avenue for therapeutic strategies for the disorder. Small molecules and FDAapproved chemicals that aim at UPR and ER homeostasis may be beneficial and promising. Gene therapy for delivering key ER chaperones or UPR proteins to the pancreas may also provide protection (Fig. 3). Further investigation on the precise mechanisms and contribution of each 
individual UPR pathway/molecule in response to ER stress in alcoholic pancreatitis could provide insight for novel therapeutic strategies for the disease.

\section{Acknowledgements}

We thank Joyce Gao for proofreading the manuscript. This work was supported by the National Institutes of Health (NIH) grants AA017226, AA026344, and AA015407. It was also supported in part by the Department of Veterans Affairs, Veterans Health Administration, Office of Research and Development [Biomedical Laboratory Research and Development: Merit Review (BX001721)].

\section{Conflicts of Interest}

The authors declare no conflict of interest.

\section{References}

[1] Lankisch PG, Apte M, Banks PA: Acute pancreatitis. Lancet (London, England) 2015, 386:85-96. [2] Yadav D, Lowenfels AB: The epidemiology of pancreatitis and pancreatic cancer. Gastroenterology 2013, 144:1252-61.

[3] Xiao AY, Tan ML, Wu LM, Asrani VM, Windsor JA, Yadav D, Petrov MS: Global incidence and mortality of pancreatic diseases: a systematic review, meta-analysis, and meta-regression of population-based cohort studies. The Lancet Gastroenterology \& Hepatology 2016, 1:45-55.

[4] Peery AF, Dellon ES, Lund J, Crockett SD, McGowan CE, Bulsiewicz WJ, Gangarosa LM, Thiny MT, Stizenberg K, Morgan DR: Burden of gastrointestinal disease in the United States: 2012 update. Gastroenterology 2012, 143:1179-87. e3.

[5] Yadav D, Lowenfels AB: Trends in the epidemiology of the first attack of acute pancreatitis: a systematic review. Pancreas 2006, 33:323-30.

[6] Weiss FU, Laemmerhirt F, Lerch MM: Etiology and risk factors of acute and chronic pancreatitis. Visceral medicine 2019, 35:73-81.

[7] Lankisch PG, Lowenfels AB, Maisonneuve P: What is the risk of alcoholic pancreatitis in heavy drinkers? Pancreas 2002, 25:411-.

[8] Boxhoorn L, Voermans RP, Bouwense SA, Bruno MJ, Verdonk RC, Boermeester MA, van Santvoort HC, Besselink MG: Acute pancreatitis. Lancet (London, England) 2020, 396:726-34.

[9] Banks PA, Bollen TL, Dervenis C, Gooszen HG, Johnson CD, Sarr MG, Tsiotos GG, Vege SS:

Classification of acute pancreatitis--2012: revision of the Atlanta classification and definitions by international consensus. Gut 2013, 62:102-11.

[10] Bugiantella W, Rondelli F, Boni M, Stella P, Polistena A, Sanguinetti A, Avenia N: Necrotizing pancreatitis: A review of the interventions. International journal of surgery 2016, 28:S163-S71. 
[11] Ali UA, Issa Y, Hagenaars JC, Bakker OJ, van Goor H, Nieuwenhuijs VB, Bollen TL, van Ramshorst B, Witteman BJ, Brink MA: Risk of recurrent pancreatitis and progression to chronic pancreatitis after a first episode of acute pancreatitis. Clinical gastroenterology and hepatology 2016, 14:738-46.

[12] Vipperla K, Papachristou GI, Easler J, Muddana V, Slivka A, Whitcomb DC, Yadav D: Risk of and factors associated with readmission after a sentinel attack of acute pancreatitis. Clinical Gastroenterology and Hepatology 2014, 12:1911-9.

[13] Hollemans RA, Hallensleben ND, Mager DJ, Kelder JC, Besselink MG, Bruno MJ, Verdonk RC, van Santvoort HC, Group DPS: Pancreatic exocrine insufficiency following acute pancreatitis: Systematic review and study level meta-analysis. Pancreatology 2018, 18:253-62.

[14] Huang W, de la Iglesia-García D, Baston-Rey I, Calviño-Suarez C, Lariño-Noia J, Iglesias-Garcia J, Shi $N$, Zhang X, Cai W, Deng L: Exocrine pancreatic insufficiency following acute pancreatitis: systematic review and meta-analysis. Digestive diseases and sciences 2019, 64:1985-2005.

[15] Das SL, Singh PP, Phillips AR, Murphy R, Windsor JA, Petrov MS: Newly diagnosed diabetes mellitus after acute pancreatitis: a systematic review and meta-analysis. Gut 2014, 63:818-31.

[16] Shen H-N, Yang C-C, Chang Y-H, Lu C-L, Li C-Y: Risk of diabetes mellitus after first-attack acute pancreatitis: a national population-based study. American Journal of Gastroenterology 2015, 110:1698706.

[17] Sadr-Azodi O, Oskarsson V, Discacciati A, Videhult P, Askling J, Ekbom A: Pancreatic cancer following acute pancreatitis: a population-based matched cohort study. American Journal of Gastroenterology 2018, 113:1711-9.

[18] Kirkegård J, Cronin-Fenton D, Heide-Jørgensen U, Mortensen FV: Acute pancreatitis and pancreatic cancer risk: a nationwide matched-cohort study in Denmark. Gastroenterology 2018, 154:1729-36.

[19] Singh VK, Yadav D, Garg PK: Diagnosis and Management of Chronic Pancreatitis: A Review. Jama 2019, 322:2422-34.

[20] Majumder S, Chari ST: Chronic pancreatitis. Lancet (London, England) 2016, 387:1957-66.

[21] Lindkvist B, Domínguez-Muñoz JE, Luaces-Regueira M, Castiñeiras-Alvariño M, Nieto-Garcia L, Iglesias-Garcia J: Serum nutritional markers for prediction of pancreatic exocrine insufficiency in chronic pancreatitis. Pancreatology 2012, 12:305-10.

[22] Layer P, Yamamoto H, Kalthoff L, Clain JE, Bakken L, DiMagno EP: The different courses of early-and late-onset idiopathic and alcoholic chronic pancreatitis. Gastroenterology 1994, 107:1481-7.

[23] Kirkegård J, Mortensen FV, Cronin-Fenton D: Chronic pancreatitis and pancreatic cancer risk: a systematic review and meta-analysis. American Journal of Gastroenterology 2017, 112:1366-72.

[24] Brodovicz K, Kou T, Alexander C, O'Neill E, Engel S, Girman C, Goldstein B: Impact of diabetes duration and chronic pancreatitis on the association between type 2 diabetes and pancreatic cancer risk. Diabetes, Obesity and Metabolism 2012, 14:1123-8.

[25] Malka D, Hammel P, Sauvanet A, Rufat P, O'Toole D, Bardet P, Belghiti J, Bernades P, Ruszniewski P, Lévy P: Risk factors for diabetes mellitus in chronic pancreatitis. Gastroenterology 2000, 119:1324-32.

[26] Hardt PD, Killinger A, Nalop J, Schnell-Kretschmer H, Zekorn T, Klör HU: Chronic pancreatitis and diabetes mellitus. Pancreatology 2002, 2:30-3.

[27] Forsmark CE, Vege SS, Wilcox CM: Acute Pancreatitis. The New England journal of medicine 2016, 375:1972-81.

[28] Kleeff J, Whitcomb DC, Shimosegawa T, Esposito I, Lerch MM, Gress T, Mayerle J, Drewes AM, Rebours V, Akisik F, Muñoz JED, Neoptolemos JP: Chronic pancreatitis. Nature reviews Disease primers 2017, 3:17060.

[29] Bertilsson S, Swärd P, Kalaitzakis E: Factors that affect disease progression after first attack of acute pancreatitis. Clinical Gastroenterology and Hepatology 2015, 13:1662-9. e3.

[30] Dreiling DA, Koller M: The natural history of alcoholic pancreatitis: update 1985. The Mount Sinai journal of medicine, New York 1985, 52:340-2. 
[31] Kristiansen L, Grønbaek M, Becker U, Tolstrup JS: Risk of pancreatitis according to alcohol drinking habits: a population-based cohort study. Am J Epidemiol 2008, 168:932-7.

[32] Lankisch PG, Lowenfels AB, Maisonneuve P: What is the risk of alcoholic pancreatitis in heavy drinkers? Pancreas 2002, 25:411-2.

[33] Yadav D: Recent advances in the epidemiology of alcoholic pancreatitis. Curr Gastroenterol Rep 2011, 13:157-65.

[34] Corrao G, Bagnardi V, Zambon A, La Vecchia C: A meta-analysis of alcohol consumption and the risk of 15 diseases. Preventive medicine 2004, 38:613-9.

[35] Irving HM, Samokhvalov AV, Rehm J: Alcohol as a risk factor for pancreatitis. A systematic review and meta-analysis. Jop 2009, 10:387.

[36] Yadav D, Whitcomb DC: The role of alcohol and smoking in pancreatitis. Nature reviews Gastroenterology \& hepatology 2010, 7:131.

[37] Kristiansen L, Grønbæk M, Becker U, Tolstrup JS: Risk of pancreatitis according to alcohol drinking habits: a population-based cohort study. American journal of epidemiology 2008, 168:932-7.

[38] Yadav D, Hawes RH, Brand RE, Anderson MA, Money ME, Banks PA, Bishop MD, Baillie J, Sherman S, DiSario J, Burton FR, Gardner TB, Amann ST, Gelrud A, Lawrence C, Elinoff B, Greer JB, O'Connell M, Barmada MM, Slivka A, Whitcomb DC: Alcohol consumption, cigarette smoking, and the risk of recurrent acute and chronic pancreatitis. Archives of internal medicine 2009, 169:1035-45.

[39] Irving HM, Samokhvalov AV, Rehm J: Alcohol as a risk factor for pancreatitis. A systematic review and meta-analysis. Jop 2009, 10:387-92.

[40] Jaakkola M, Sillanaukee P, Löf K, Koivula T, Nordback I: Amount of alcohol is an important determinant of the severity of acute alcoholic pancreatitis. Surgery 1994, 115:31-8.

[41] Phillip V, Huber W, Hagemes F, Lorenz S, Matheis U, Preinfalk S, Schuster T, Lippl F, Saugel B, Schmid RM: Incidence of acute pancreatitis does not increase during Oktoberfest, but is higher than previously described in Germany. Clinical gastroenterology and hepatology : the official clinical practice journal of the American Gastroenterological Association 2011, 9:995-1000.e3.

[42] Takeyama Y: Long-term prognosis of acute pancreatitis in Japan. Clinical gastroenterology and hepatology 2009, 7:S15-S7.

[43] Lankisch MR, Imoto M, Layer P, DiMagno EP: The effect of small amounts of alcohol on the clinical course of chronic pancreatitis. Mayo Clinic proceedings 2001, 76:242-51.

[44] Setiawan VW, Pandol SJ, Porcel J, Wilkens LR, Le Marchand L, Pike MC, Monroe KR: Prospective study of alcohol drinking, smoking and pancreatitis: the multiethnic cohort. Pancreas 2016, 45:819.

[45] Strum WB: Abstinence in alcoholic chronic pancreatitis. Effect on pain and outcome. Journal of clinical gastroenterology 1995, 20:37-41.

[46] Nikkola J, Räty S, Laukkarinen J, Seppänen H, Lappalainen-Lehto R, Järvinen S, Nordback I, Sand J: Abstinence after first acute alcohol-associated pancreatitis protects against recurrent pancreatitis and minimizes the risk of pancreatic dysfunction. Alcohol and alcoholism 2013, 48:483-6.

[47] Pelli H, Lappalainen-Lehto R, Piironen A, Sand J, Nordback I: Risk factors for recurrent acute alcoholassociated pancreatitis: a prospective analysis. Scandinavian journal of gastroenterology 2008, 43:61421.

[48] Pandol SJ, Lugea A, Mareninova OA, Smoot D, Gorelick FS, Gukovskaya AS, Gukovsky I: Investigating the pathobiology of alcoholic pancreatitis. Alcoholism: Clinical and Experimental Research 2011, 35:8307.

[49] Sadr-Azodi O, Andrén-Sandberg Å, Orsini N, Wolk A: Cigarette smoking, smoking cessation and acute pancreatitis: a prospective population-based study. Gut 2012, 61:262-7.

[50] Lin Y, Tamakoshi A, Hayakawa T, Ogawa M, Ohno Y, Diseases RCoIP: Cigarette smoking as a risk factor for chronic pancreatitis: a case-control study in Japan. Pancreas 2000, 21:109-14. 
[51] Lowenfels AB, Maisonneuve P, Whitcomb DC, Lerch MM, DiMagno EP: Cigarette Smoking as a Risk Factor for Pancreatic Cancer in Patients With Hereditary Pancreatitis. Jama 2001, 286:169-70.

[52] Fuchs CS, Colditz GA, Stampfer MJ, Giovannucci EL, Hunter DJ, Rimm EB, Willett WC, Speizer FE: A prospective study of cigarette smoking and the risk of pancreatic cancer. Archives of internal medicine 1996, 156:2255-60.

[53] Greer JB, Thrower E, Yadav D: Epidemiologic and mechanistic associations between smoking and pancreatitis. Current treatment options in gastroenterology 2015, 13:332-46.

[54] Talamini G, Bassi C, Falconi M, Frulloni L, Di Francesco V, Vaona B, Bovo P, Rigo L, Castagnini A, Angelini G: Cigarette smoking: an independent risk factor in alcoholic pancreatitis. Pancreas 1996,

12:131-7.

[55] Yadav D, Hawes RH, Brand RE, Anderson MA, Money ME, Banks PA, Bishop MD, Baillie J, Sherman S, DiSario J: Alcohol consumption, cigarette smoking, and the risk of recurrent acute and chronic pancreatitis. Archives of internal medicine 2009, 169:1035-45.

[56] Maisonneuve P, Lowenfels A, Müllhaupt B, Cavallini G, Lankisch P, Andersen J, Dimagno E, AndrénSandberg Å, Domellöf L, Frulloni L: Cigarette smoking accelerates progression of alcoholic chronic pancreatitis. Gut 2005, 54:510-4.

[57] Zhu Y, Pan X, Zeng H, He W, Xia L, Liu P, Zhu Y, Chen Y, Lv N: A Study on the Etiology, Severity, and Mortality of 3260 Patients With Acute Pancreatitis According to the Revised Atlanta Classification in Jiangxi, China Over an 8-Year Period. Pancreas 2017, 46:504-9.

[58] Toskes PP: Hyperlipidemic pancreatitis. Gastroenterology clinics of North America 1990, 19:783-91.

[59] Vipperla K, Somerville C, Furlan A, Koutroumpakis E, Saul M, Chennat J, Rabinovitz M, Whitcomb

DC, Slivka A, Papachristou GI, Yadav D: Clinical Profile and Natural Course in a Large Cohort of Patients With Hypertriglyceridemia and Pancreatitis. J Clin Gastroenterol 2017, 51:77-85.

[60] Klop B, do Rego AT, Cabezas MC: Alcohol and plasma triglycerides. Current opinion in lipidology 2013, 24:321-6.

[61] Bessembinders K, Wielders J, van de Wiel A: Severe hypertriglyceridemia influenced by alcohol (SHIBA). Alcohol and alcoholism 2011, 46:113-6.

[62] Garg R, Rustagi T: Management of hypertriglyceridemia induced acute pancreatitis. BioMed research international 2018, 2018.

[63] Fortson MR, Freedman SN, Webster PD, 3rd: Clinical assessment of hyperlipidemic pancreatitis. The American journal of gastroenterology 1995, 90:2134-9.

[64] Rosenthal R, Günzel D, Krug SM, Schulzke JD, Fromm M, Yu AS: Claudin-2-mediated cation and water transport share a common pore. Acta physiologica (Oxford, England) 2017, 219:521-36.

[65] Aung PP, Mitani Y, Sanada Y, Nakayama H, Matsusaki K, Yasui W: Differential expression of claudin2 in normal human tissues and gastrointestinal carcinomas. Virchows Archiv 2006, 448:428-34.

[66] Whitcomb DC, LaRusch J, Krasinskas AM, Klei L, Smith JP, Brand RE, Neoptolemos JP, Lerch MM, Tector M, Sandhu BS: Common genetic variants in the CLDN2 and PRSS1-PRSS2 loci alter risk for alcoholrelated and sporadic pancreatitis. Nature genetics 2012, 44:1349-54.

[67] Rosendahl J, Kirsten H, Hegyi E, Kovacs P, Weiss FU, Laumen H, Lichtner P, Ruffert C, Chen J-M, Masson E: Genome-wide association study identifies inversion in the CTRB1-CTRB2 locus to modify risk for alcoholic and non-alcoholic chronic pancreatitis. Gut 2018, 67:1855-63.

[68] Yang AL, Vadhavkar S, Singh G, Omary MB: Epidemiology of Alcohol-Related Liver and Pancreatic Disease in the United States. Archives of internal medicine 2008, 168:649-56.

[69] Wilcox CM, Sandhu BS, Singh V, Gelrud A, Abberbock JN, Sherman S, Cote GA, Al-Kaade S, Anderson MA, Gardner TB, Lewis MD, Forsmark CE, Guda NM, Romagnuolo J, Baillie J, Amann ST, Muniraj T, Tang G, Conwell DL, Banks PA, Brand RE, Slivka A, Whitcomb D, Yadav D: Racial Differences in the Clinical Profile, Causes, and Outcome of Chronic Pancreatitis. The American journal of gastroenterology 2016, 111:1488-96. 
[70] Lin HH, Chang HY, Chiang YT, Wu MS, Lin JT, Liao WC: Smoking, drinking, and pancreatitis: a population-based cohort study in Taiwan. Pancreas 2014, 43:1117-22.

[71] Samokhvalov AV, Rehm J, Roerecke M: Alcohol Consumption as a Risk Factor for Acute and Chronic Pancreatitis: A Systematic Review and a Series of Meta-analyses. EBioMedicine 2015, 2:1996-2002.

[72] Kume K, Masamune A, Ariga H, Shimosegawa T: Alcohol Consumption and the Risk for Developing Pancreatitis: A Case-Control Study in Japan. Pancreas 2015, 44:53-8.

[73] Chen YJ, Chen C, Wu DC, Lee CH, Wu Cl, Lee JM, Goan YG, Huang SP, Lin CC, Li TC, Chou YP, Wu MT: Interactive effects of lifetime alcohol consumption and alcohol and aldehyde dehydrogenase polymorphisms on esophageal cancer risks. Int J Cancer 2006, 119:2827-31.

[74] Lee CH, Lee JM, Wu DC, Goan YG, Chou SH, Wu IC, Kao EL, Chan TF, Huang MC, Chen PS, Lee CY, Huang $\mathrm{CT}$, Huang HL, Hu CY, Hung YH, Wu MT: Carcinogenetic impact of ADH1B and ALDH2 genes on squamous cell carcinoma risk of the esophagus with regard to the consumption of alcohol, tobacco and betel quid. Int J Cancer 2008, 122:1347-56.

[75] Chen YJ, Chen C, Wu DC, Lee CH, Wu Cl, Lee JM, Goan YG, Huang SP, Lin CC, Li TC: Interactive effects of lifetime alcohol consumption and alcohol and aldehyde dehydrogenase polymorphisms on esophageal cancer risks. International journal of cancer 2006, 119:2827-31.

[76] Yokoyama A, Mizukami T, Matsui T, Yokoyama T, Kimura M, Matsushita S, Higuchi S, Maruyama K: Genetic polymorphisms of alcohol dehydrogenase-1B and aldehyde dehydrogenase- 2 and liver cirrhosis, chronic calcific pancreatitis, diabetes mellitus, and hypertension among Japanese alcoholic men. Alcoholism, clinical and experimental research 2013, 37:1391-401.

[77] Schneider L, Dieckmann R, Hackert T, Gebhard MM, Werner J: Acute alcohol-induced pancreatic injury is similar with intravenous and intragastric routes of alcohol administration. Pancreas 2014, 43:6974.

[78] Gukovsky I, Lugea A, Shahsahebi M, Cheng JH, Hong PP, Jung YJ, Deng Q-g, French BA, Lungo W, French SW: A rat model reproducing key pathological responses of alcoholic chronic pancreatitis. American Journal of Physiology-Gastrointestinal and Liver Physiology 2008, 294:G68-G79.

[79] Schneider L, Pietschmann M, Hartwig W, Hackert T, Marcos SS, Longerich T, Gebhard M-M, Buchler $\mathrm{MW}$, Wemer J: Alcohol pretreatment increases hepatic and pulmonary injury in experimental pancreatitis. Pancreatology 2009, 9:258-66.

[80] Lugea A, Tischler D, Nguyen J, Gong J, Gukovsky I, French SW, Gorelick FS, Pandol SJ: Adaptive unfolded protein response attenuates alcohol-induced pancreatic damage. Gastroenterology 2011, 140:987-97. e8.

[81] Ren Z, Wang X, Xu M, Yang F, Frank JA, Ke Z-j, Luo J: Binge ethanol exposure causes endoplasmic reticulum stress, oxidative stress and tissue injury in the pancreas. Oncotarget 2016, 7:54303.

[82] Ren Z, Yang F, Wang X, Wang Y, Xu M, Frank JA, Ke Z-j, Zhang Z, Shi X, Luo J: Chronic plus binge ethanol exposure causes more severe pancreatic injury and inflammation. Toxicology and applied pharmacology 2016, 308:11-9.

[83] Bertola A, Mathews S, Ki SH, Wang H, Gao B: Mouse model of chronic and binge ethanol feeding (the NIAAA model). Nature protocols 2013, 8:627-37.

[84] Wang S, Ni H-M, Chao X, Ma X, Kolodecik T, De Lisle R, Ballabio A, Pacher P, Ding W-X: Critical role of TFEB-mediated lysosomal biogenesis in alcohol-induced pancreatitis in mice and humans. Cellular and Molecular Gastroenterology and Hepatology 2020.

[85] Sloan F, Grossman D, Platt A: Heavy episodic drinking in early adulthood and outcomes in midlife. Journal of studies on alcohol and drugs 2011, 72:459-70.

[86] Choi G, Runyon BA: Alcoholic hepatitis: a clinician's guide. Clin Liver Dis 2012, 16:371-85.

[87] Mathurin P, Lucey MR: Management of alcoholic hepatitis. Journal of hepatology 2012, 56:S39-S45. 
[88] Ki SH, Park O, Zheng M, Morales-Ibanez O, Kolls JK, Bataller R, Gao B: Interleukin-22 treatment ameliorates alcoholic liver injury in a murine model of chronic-binge ethanol feeding: role of signal transducer and activator of transcription 3. Hepatology (Baltimore, Md) 2010, 52:1291-300.

[89] Gao B, Xu M-J, Bertola A, Wang H, Zhou Z, Liangpunsakul S: Animal models of alcoholic liver disease: pathogenesis and clinical relevance. Gene expression 2017, 17:173.

[90] Lampel M, Kern HF: Acute interstitial pancreatitis in the rat induced by excessive doses of a pancreatic secretagogue. Virchows Archiv A 1977, 373:97-117.

[91] Wisner J, Green D, Ferrell L, Renner I: Evidence for a role of oxygen derived free radicals in the pathogenesis of caerulein induced acute pancreatitis in rats. Gut 1988, 29:1516-23.

[92] Pandol SJ, Periskic S, Gukovsky I, Zaninovic V, Jung Y, Zong Y, Solomon TE, Gukovskaya AS, Tsukamoto $\mathrm{H}$ : Ethanol diet increases the sensitivity of rats to pancreatitis induced by cholecystokinin octapeptide. Gastroenterology 1999, 117:706-16.

[93] Rongione AJ, Kusske A, Kwan K, Ashley SW, Reber HA, McFadden DW: Interleukin 10 reduces the severity of acute pancreatitis in rats. Gastroenterology 1997, 112:960-7.

[94] Virlos I, Mazzon E, Serraino I, Di Paola R, Genovese T, Britti D, Thiemerman C, Siriwardena A, Cuzzocrea S: Pyrrolidine dithiocarbamate reduces the severity of cerulein-induced murine acute pancreatitis. Shock 2003, 20:544-50.

[95] Niederau C, Ferrell LD, Grendell JH: Caerulein-induced acute necrotizing pancreatitis in mice; protective effects of Proglumide Benzotript, and Secretin. Gastroenterology 1985, 88:1192-204.

[96] Demols A, Van Laethem J-L, Quertinmont E, Legros F, Louis H, Le Moine O, Devière J: Nacetylcysteine decreases severity of acute pancreatitis in mice. Pancreas 2000, 20:161-9.

[97] Genovese T, Mazzon E, Di Paola R, Muià C, Crisafulli C, Menegazzi M, Malleo G, Suzuki H, Cuzzocrea $\mathrm{S}$ : Hypericum perforatum attenuates the development of cerulein-induced acute pancreatitis in mice. Shock 2006, 25:161-7.

[98] Bartholomew C: Acute scorpion pancreatitis in Trinidad. Br Med J 1970, 1:666-8.

[99] Singh S, Bhardwaj U, Verma SK, Bhalla A, Gill K: Hyperamylasemia and acute pancreatitis following anticholinesterase poisoning. Human \& experimental toxicology 2007, 26:467-71.

[100] Becerril B, Marangoni S, Possani LD: Toxins and genes isolated from scorpions of the genus Tityus. Toxicon 1997, 35:821-35.

[101] Fletcher Jr P, Fletcher M, Possani L: Characteristics of pancreatic exocrine secretion produced by venom from the Brazilian scorpion, Tityus serrulatus. European journal of cell biology 1992, 58:259-70. [102] Quon MG, Kugelmas M, Wisner JR, Chandrasoma P, Valenzuela JE: Chronic alcohol consumption intensifies caerulein-induced acute pancreatitis in the rat. International journal of pancreatology 1992, 12:31-9.

[103] Neuschwander-Tetri BA, Burton FR, Presti ME, Britton RS, Janney CG, Garvin PR, Brunt EM, Galvin NJ, Poulos JE: Repetitive self-limited acute pancreatitis induces pancreatic fibrogenesis in the mouse. Digestive diseases and sciences 2000, 45:665-74.

[104] Ulmasov B, Oshima K, Rodriguez MG, Cox RD, Neuschwander-Tetri BA: Differences in the degree of cerulein-induced chronic pancreatitis in C57BL/6 mouse substrains lead to new insights in identification of potential risk factors in the development of chronic pancreatitis. The American Journal of Pathology 2013, 183:692-708.

[105] Deng X, Wang L, Elm MS, Gabazadeh D, Diorio GJ, Eagon PK, Whitcomb DC: Chronic alcohol consumption accelerates fibrosis in response to cerulein-induced pancreatitis in rats. Am J Pathol 2005, 166:93-106.

[106] Perides G, Tao X, West N, Sharma A, Steer ML: A mouse model of ethanol dependent pancreatic fibrosis. Gut 2005, 54:1461-7. 
[107] Vonlaufen A, Xu Z, Daniel B, Kumar RK, Pirola R, Wilson J, Apte MV: Bacterial endotoxin: a trigger factor for alcoholic pancreatitis? Evidence from a novel, physiologically relevant animal model. Gastroenterology 2007, 133:1293-303.

[108] Parlesak A: Alcohol, Altered Gut Permeability, and Endotoxins. Comprehensive Handbook of Alcohol Related Pathology: Elsevier, 2005. pp. 965-77.

[109] Bode C, Kugler V, Bode J: Endotoxemia in patients with alcoholic and non-alcoholic cirrhosis and in subjects with no evidence of chronic liver disease following acute alcohol excess. Journal of hepatology 1987, 4:8-14.

[110] Fukui H, Brauner B, Bode JC, Bode C: Plasma endotoxin concentrations in patients with alcoholic and non-alcoholic liver disease: reevaluation with an improved chromogenic assay. Journal of hepatology 1991, 12:162-9.

[111] Ammori BJ, Leeder PC, King RF, Barclay GR, Martin IG, Larvin M, McMahon MJ: Early increase in intestinal permeability in patients with severe acute pancreatitis: correlation with endotoxemia, organ failure, and mortality. Journal of gastrointestinal surgery 1999, 3:252-62.

[112] Fortunato F, Deng X, Gates LK, McClain CJ, Bimmler D, Graf R, Whitcomb DC: Pancreatic response to endotoxin after chronic alcohol exposure: switch from apoptosis to necrosis? American journal of physiology Gastrointestinal and liver physiology 2006, 290:G232-41.

[113] Vonlaufen A, Phillips PA, Xu Z, Zhang X, Yang L, Pirola RC, Wilson JS, Apte MV: Withdrawal of alcohol promotes regression while continued alcohol intake promotes persistence of LPS-induced pancreatic injury in alcohol-fed rats. Gut 2011, 60:238-46.

[114] Gu H, Werner J, Bergmann F, Whitcomb D, Büchler M, Fortunato F: Necro-inflammatory response of pancreatic acinar cells in the pathogenesis of acute alcoholic pancreatitis. Cell death \& disease 2013, 4:e816-e.

[115] Grauvogel J, Daemmrich T, Ryschich E, Gebhard M, Werner J: Chronic alcohol intake increases the severity of pancreatitis induced by acute alcohol administration, hyperlipidemia and pancreatic duct obstruction in rats. Pancreatology 2010, 10:603-12.

[116] Orekhova A, Geisz A, Sahin-Tóth M: Ethanol feeding accelerates pancreatitis progression in CPA1 N256K mutant mice. American Journal of Physiology-Gastrointestinal and Liver Physiology 2020, 318:G694-G704.

[117] Sun J, Fu J, Zhong Y, Li L, Chen C, Wang X, Wang L, Hou Y, Wang H, Zhao R: NRF2 mitigates acute alcohol-induced hepatic and pancreatic injury in mice. Food and Chemical Toxicology 2018, 121:495503.

[118] Amsterdam A, Jamieson JD: Structural and functional characterization of isolated pancreatic exocrine cells. Proceedings of the National Academy of Sciences of the United States of America 1972, 69:3028-32.

[119] Saluja A, Dudeja V, Dawra R, Sah RP: Early Intra-Acinar Events in Pathogenesis of Pancreatitis. Gastroenterology 2019, 156:1979-93.

[120] Steer ML: Early events in acute pancreatitis. Bailliere's best practice \& research Clinical gastroenterology 1999, 13:213-25.

[121] Gorelick FS, Thrower E: The acinar cell and early pancreatitis responses. Clinical Gastroenterology and Hepatology 2009, 7:S10-S4.

[122] Subramanya SB, Subramanian VS, Sekar VT, Said HM: Thiamin uptake by pancreatic acinar cells: effect of chronic alcohol feeding/exposure. American Journal of Physiology-Gastrointestinal and Liver Physiology 2011, 301:G896-G904.

[123] Srinivasan P, Nabokina S, Said HM: Chronic alcohol exposure affects pancreatic acinar mitochondrial thiamin pyrophosphate uptake: studies with mouse 266-6 cell line and primary cells. American Journal of Physiology-Gastrointestinal and Liver Physiology 2015, 309:G750-G8. 
[124] Singh M: Effect of thiamin deficiency on pancreatic acinar cell function. The American journal of clinical nutrition 1982, 36:500-4.

[125] Rathanaswami P, Pourany A, Sundaresan R: Effects of thiamine deficiency on the secretion of insulin and the metabolism of glucose in isolated rat pancreatic islets. Biochemistry international 1991, 25:577.

[126] Rathanaswami P, Sundaresan R: Effects of thiamine deficiency on the biosynthesis of insulin in rats. Biochemistry international 1991, 24:1057.

[127] Wu H, Bhopale KK, Ansari G, Kaphalia BS: Ethanol-induced cytotoxicity in rat pancreatic acinar AR42J cells: role of fatty acid ethyl esters. Alcohol \& Alcoholism 2008, 43:1-8.

[128] Lugea A, Gerloff A, Su H-Y, Xu Z, Go A, Hu C, French SW, Wilson JS, Apte MV, Waldron RT: The combination of alcohol and cigarette smoke induces endoplasmic reticulum stress and cell death in pancreatic acinar cells. Gastroenterology 2017, 153:1674-86.

[129] González A, Pariente JA, Salido GM: Ethanol impairs calcium homeostasis following CCK-8 stimulation in mouse pancreatic acinar cells. Alcohol 2008, 42:565-73.

[130] Fernández-Sánchez M, del Castillo-Vaquero A, Salido GM, González A: Ethanol exerts dual effects on calcium homeostasis in CCK-8-stimulated mouse pancreatic acinar cells. BMC cell biology 2009, 10:77.

[131] González A, Núñez AM, Granados MP, Pariente JA, Salido GM: Ethanol impairs CCK-8-evoked amylase secretion through $\mathrm{Ca2+-mediated} \mathrm{ROS} \mathrm{generation} \mathrm{in} \mathrm{mouse} \mathrm{pancreatic} \mathrm{acinar} \mathrm{cells.} \mathrm{Alcohol}$ 2006, 38:51-7.

[132] Orabi Al, Shah AU, Muili K, Luo Y, Mahmood SM, Ahmad A, Reed A, Husain SZ: Ethanol enhances carbachol-induced protease activation and accelerates $\mathrm{Ca} 2+$ waves in isolated rat pancreatic acini. The Journal of biological chemistry 2011, 286:14090-7.

[133] Hegyi P, Pandol S, Venglovecz V, Rakonczay Z: The acinar-ductal tango in the pathogenesis of acute pancreatitis. Gut 2011, 60:544-52.

[134] Wilschanski M, Novak I: The cystic fibrosis of exocrine pancreas. Cold Spring Harbor perspectives in medicine 2013, 3:a009746.

[135] LaRusch J, Whitcomb DC: Genetics of pancreatitis with a focus on the pancreatic ducts. Minerva gastroenterologica e dietologica 2012, 58:299.

[136] Sarles H, Sarles J-C, Camatte R, Muratore R, Gaini M, Guien C, Pastor J, Le Roy F: Observations on 205 confirmed cases of acute pancreatitis, recurring pancreatitis, and chronic pancreatitis. Gut 1965, 6:545.

[137] Sharer N, Schwarz M, Malone G, Howarth A, Painter J, Super M, Braganza J: Mutations of the cystic fibrosis gene in patients with chronic pancreatitis. The New England journal of medicine 1998, 339:64552.

[138] Maléth J, Balázs A, Pallagi P, Balla Z, Kui B, Katona M, Judák L, Németh I, Kemény LV, Rakonczay Jr $Z$ : Alcohol disrupts levels and function of the cystic fibrosis transmembrane conductance regulator to promote development of pancreatitis. Gastroenterology 2015, 148:427-39. e16.

[139] Schröder M: Endoplasmic reticulum stress responses. Cellular and molecular life sciences 2008, 65:862-94.

[140] Bravo R, Parra V, Gatica D, Rodriguez AE, Torrealba N, Paredes F, Wang ZV, Zorzano A, Hill JA, Jaimovich $E$ : Endoplasmic reticulum and the unfolded protein response: dynamics and metabolic integration. International review of cell and molecular biology: Elsevier, 2013. pp. 215-90.

[141] Kubisch CH, Sans MD, Arumugam T, Ernst SA, Williams JA, Logsdon CD: Early activation of endoplasmic reticulum stress is associated with arginine-induced acute pancreatitis. American journal of physiology Gastrointestinal and liver physiology 2006, 291:G238-45. 
[142] Ji B, Chen X-q, Misek DE, Kuick R, Hanash S, Ernst S, Najarian R, Logsdon CD: Pancreatic gene expression during the initiation of acute pancreatitis: identification of EGR-1 as a key regulator. Physiological genomics 2003, 14:59-72.

[143] Sah RP, Garg SK, Dixit AK, Dudeja V, Dawra RK, Saluja AK: Endoplasmic reticulum stress is chronically activated in chronic pancreatitis. Journal of Biological Chemistry 2014, 289:27551-61. [144] Kereszturi É, Szmola R, Kukor Z, Simon P, Ulrich Weiss F, Lerch MM, Sahin-Tóth M: Hereditary pancreatitis caused by mutation-induced misfolding of human cationic trypsinogen: a novel disease mechanism. Human mutation 2009, 30:575-82.

[145] Le Maréchal C, Bretagne J-F, Raguénès O, Quéré I, Chen J-M, Ferec C: Identification of a novel pancreatitis-associated missense mutation, R116C, in the human cationic trypsinogen gene (PRSS1). Molecular genetics and metabolism 2001, 74:342-4.

[146] Tautermann G, Ruebsamen H, Beck M, Dertinger S, Drexel H, Lohse P: R116C mutation of cationic trypsinogen in a Turkish family with recurrent pancreatitis illustrates genetic microheterogeneity of hereditary pancreatitis. Digestion 2001, 64:226-32.

[147] Pho-lam T, Thongnoppakhun W, Yenchitsomanus P-T, Limwongse C: A Thai family with hereditary pancreatitis and increased cancer risk due to a mutation in PRSS1 gene. World Journal of Gastroenterology: WJG 2005, 11:1634.

[148] Kubisch CH, Gukovsky I, Lugea A, Pandol SJ, Kuick R, Misek DE, Hanash SM, Logsdon CD: Long-term ethanol consumption alters pancreatic gene expression in rats: a possible connection to pancreatic injury. Pancreas 2006, 33:68-76.

[149] Waldron RT, Su H-Y, Piplani H, Capri J, Cohn W, Whitelegge JP, Faull KF, Sakkiah S, Abrol R, Yang W: Ethanol induced disordering of pancreatic acinar cell endoplasmic reticulum: an ER stress/defective unfolded protein response model. Cellular and molecular gastroenterology and hepatology 2018, 5:47997.

[150] Kaufman RJ: Orchestrating the unfolded protein response in health and disease. The Journal of clinical investigation 2002, 110:1389-98.

[151] Ron D, Walter P: Signal integration in the endoplasmic reticulum unfolded protein response. Nature reviews Molecular cell biology 2007, 8:519-29.

[152] Kim I, Xu W, Reed JC: Cell death and endoplasmic reticulum stress: disease relevance and therapeutic opportunities. Nature reviews Drug discovery 2008, 7:1013-30.

[153] Bertolotti A, Zhang Y, Hendershot LM, Harding HP, Ron D: Dynamic interaction of BiP and ER stress transducers in the unfolded-protein response. Nature cell biology 2000, 2:326-32.

[154] Shen J, Chen X, Hendershot L, Prywes R: ER stress regulation of ATF6 localization by dissociation of BiP/GRP78 binding and unmasking of Golgi localization signals. Developmental cell 2002, 3:99-111.

[155] Yoshida H: ER stress and diseases. The FEBS journal 2007, 274:630-58.

[156] Sano R, Reed JC: ER stress-induced cell death mechanisms. Biochimica et Biophysica Acta (BBA)Molecular Cell Research 2013, 1833:3460-70.

[157] Hetz C: The unfolded protein response: controlling cell fate decisions under ER stress and beyond. Nature reviews Molecular cell biology 2012, 13:89-102.

[158] Howell SH: Endoplasmic reticulum stress responses in plants. Annual review of plant biology 2013, 64:477-99.

[159] Cox JS, Shamu CE, Walter P: Transcriptional induction of genes encoding endoplasmic reticulum resident proteins requires a transmembrane protein kinase. Cell 1993, 73:1197-206.

[160] Wang XZ, Harding HP, Zhang Y, Jolicoeur EM, Kuroda M, Ron D: Cloning of mammalian Ire1 reveals diversity in the ER stress responses. The EMBO journal 1998, 17:5708-17.

[161] Yoshida H, Matsui T, Yamamoto A, Okada T, Mori K: XBP1 mRNA is induced by ATF6 and spliced by IRE1 in response to ER stress to produce a highly active transcription factor. Cell 2001, 107:881-91. 
[162] Lee A-H, Iwakoshi NN, Glimcher LH: XBP-1 regulates a subset of endoplasmic reticulum resident chaperone genes in the unfolded protein response. Molecular and cellular biology 2003, 23:7448-59. [163] Acosta-Alvear D, Zhou Y, Blais A, Tsikitis M, Lents NH, Arias C, Lennon CJ, Kluger Y, Dynlacht BD: $\mathrm{XBP} 1$ controls diverse cell type-and condition-specific transcriptional regulatory networks. Molecular cell 2007, 27:53-66.

[164] Maurel M, Chevet E, Tavernier J, Gerlo S: Getting RIDD of RNA: IRE1 in cell fate regulation. Trends in biochemical sciences 2014, 39:245-54.

[165] Han D, Lerner AG, Walle LV, Upton J-P, Xu W, Hagen A, Backes BJ, Oakes SA, Papa FR: IRE1 $\alpha$ kinase activation modes control alternate endoribonuclease outputs to determine divergent cell fates. Cell 2009, 138:562-75.

[166] Hollien J, Weissman JS: Decay of endoplasmic reticulum-localized mRNAs during the unfolded protein response. Science 2006, 313:104-7.

[167] Lee AH, Chu GC, Iwakoshi NN, Glimcher LH: XBP-1 is required for biogenesis of cellular secretory machinery of exocrine glands. The EMBO journal 2005, 24:4368-80.

[168] Iwawaki T, Akai R, Kohno K: IRE1 $\alpha$ disruption causes histological abnormality of exocrine tissues, increase of blood glucose level, and decrease of serum immunoglobulin level. PloS one 2010, 5:e13052. [169] Hess DA, Humphrey SE, Ishibashi J, Damsz B, Lee AH, Glimcher LH, Konieczny SF: Extensive pancreas regeneration following acinar-specific disruption of Xbp1 in mice. Gastroenterology 2011, 141:1463-72.

[170] Lugea A, Tischler D, Nguyen J, Gong J, Gukovsky I, French SW, Gorelick FS, Pandol SJ: Adaptive unfolded protein response attenuates alcohol-induced pancreatic damage. Gastroenterology 2011, 140:987-97.

[171] Harding HP, Zhang Y, Ron D: Protein translation and folding are coupled by an endoplasmicreticulum-resident kinase. Nature 1999, 397:271-4.

[172] Shi Y, Vattem KM, Sood R, An J, Liang J, Stramm L, Wek RC: Identification and characterization of pancreatic eukaryotic initiation factor $2 \alpha$-subunit kinase, PEK, involved in translational control. Molecular and cellular biology 1998, 18:7499-509.

[173] Harding HP, Zhang Y, Bertolotti A, Zeng H, Ron D: Perk is essential for translational regulation and cell survival during the unfolded protein response. Molecular cell 2000, 5:897-904.

[174] Ameri K, Harris AL: Activating transcription factor 4. The international journal of biochemistry \& cell biology 2008, 40:14-21.

[175] Luhr M, Torgersen ML, Szalai P, Hashim A, Brech A, Staerk J, Engedal N: The kinase PERK and the transcription factor ATF4 play distinct and essential roles in autophagy resulting from tunicamycininduced ER stress. Journal of Biological Chemistry 2019, 294:8197-217.

[176] Marciniak SJ, Yun CY, Oyadomari S, Novoa I, Zhang Y, Jungreis R, Nagata K, Harding HP, Ron D: $\mathrm{CHOP}$ induces death by promoting protein synthesis and oxidation in the stressed endoplasmic reticulum. Genes \& development 2004, 18:3066-77.

[177] Walter $P$, Ron D: The unfolded protein response: from stress pathway to homeostatic regulation. Science 2011, 334:1081-6.

[178] Armstrong JL, Flockhart R, Veal GJ, Lovat PE, Redfern CP: Regulation of endoplasmic reticulum stress-induced cell death by ATF4 in neuroectodermal tumor cells. Journal of Biological Chemistry 2010, 285:6091-100.

[179] Novoa I, Zeng H, Harding HP, Ron D: Feedback inhibition of the unfolded protein response by GADD34-mediated dephosphorylation of elF2 $\alpha$. The Journal of cell biology 2001, 153:1011-22.

[180] Zhang P, McGrath B, Frank A, Zambito F, Reinert J, Gannon M, Ma K, McNaughton K, Cavener DR: The PERK eukaryotic initiation factor $2 \alpha$ kinase is required for the development of the skeletal system, postnatal growth, and the function and viability of the pancreas. Molecular and cellular biology 2002, 22:3864-74. 
[181] Harding HP, Zeng H, Zhang Y, Jungries R, Chung P, Plesken H, Sabatini DD, Ron D: Diabetes mellitus and exocrine pancreatic dysfunction in perk-/- mice reveals a role for translational control in secretory cell survival. Molecular cell 2001, 7:1153-63.

[182] Casini A, Galli A, Pignalosa P, Frulloni L, Grappone C, Milani S, Pederzoli P, Cavallini G, Surrenti C: Collagen type I synthesized by pancreatic periacinar stellate cells (PSC) co-localizes with lipid peroxidation-derived aldehydes in chronic alcoholic pancreatitis. The Journal of pathology 2000, 192:819. [183] lida K, Li Y, McGrath BC, Frank A, Cavener DR: PERK elF2 alpha kinase is required to regulate the viability of the exocrine pancreas in mice. BMC cell biology 2007, 8:1-16.

[184] Haze K, Yoshida H, Yanagi H, Yura T, Mori K: Mammalian transcription factor ATF6 is synthesized as a transmembrane protein and activated by proteolysis in response to endoplasmic reticulum stress. Molecular biology of the cell 1999, 10:3787-99.

[185] Senkal CE, Ponnusamy S, Bielawski J, Hannun YA, Ogretmen B: Antiapoptotic roles of ceramidesynthase-6-generated C16-ceramide via selective regulation of the ATF6/CHOP arm of ER-stressresponse pathways. The FASEB Journal 2010, 24:296-308.

[186] Wu J, Rutkowski DT, Dubois M, Swathirajan J, Saunders T, Wang J, Song B, Yau GD-Y, Kaufman RJ: ATF6 $\alpha$ optimizes long-term endoplasmic reticulum function to protect cells from chronic stress.

Developmental cell 2007, 13:351-64.

[187] Yamamoto K, Sato T, Matsui T, Sato M, Okada T, Yoshida H, Harada A, Mori K: Transcriptional induction of mammalian ER quality control proteins is mediated by single or combined action of ATF $6 \alpha$ and XBP1. Developmental cell 2007, 13:365-76.

[188] Zhou L, Tan J-h, Cao R-c, Xu J, Chen X-m, Qi Z-c, Zhou S-y, Li S-b, Mo Q-x, Li Z-w: ATF6 regulates the development of chronic pancreatitis by inducing p53-mediated apoptosis. Cell death \& disease 2019, 10:1-12.

[189] Yoshida H, Matsui T, Hosokawa N, Kaufman RJ, Nagata K, Mori K: A time-dependent phase shift in the mammalian unfolded protein response. Developmental cell 2003, 4:265-71.

[190] DuRose JB, Tam AB, Niwa M: Intrinsic capacities of molecular sensors of the unfolded protein response to sense alternate forms of endoplasmic reticulum stress. Molecular biology of the cell 2006, 17:3095-107.

[191] Srinivasan MP, Bhopale KK, Caracheo AA, Amer SM, Khan S, Kaphalia L, Loganathan G, Balamurugan AN, Kaphalia BS: Activation of AMP-activated protein kinase attenuates ethanol-induced ER/oxidative stress and lipid phenotype in human pancreatic acinar cells. Biochemical Pharmacology 2020, 180:114174.

[192] Ren Z, Wang X, Xu M, Yang F, Frank JA, Ke ZJ, Luo J: Binge ethanol exposure causes endoplasmic reticulum stress, oxidative stress and tissue injury in the pancreas. Oncotarget 2016, 7:54303-16.

[193] Halliday M, Radford H, Zents KA, Molloy C, Moreno JA, Verity NC, Smith E, Ortori CA, Barrett DA, Bushell M: Repurposed drugs targeting elF2 $\alpha$-P-mediated translational repression prevent neurodegeneration in mice. Brain 2017, 140:1768-83.

[194] Hetz C, Axten JM, Patterson JB: Pharmacological targeting of the unfolded protein response for disease intervention. Nature chemical biology 2019, 15:764-75.

[195] Hetz C, Chevet E, Harding HP: Targeting the unfolded protein response in disease. Nature reviews Drug discovery 2013, 12:703-19.

[196] Perlmutter DH: Chemical chaperones: a pharmacological strategy for disorders of protein folding and trafficking. Pediatric research 2002, 52:832-6.

[197] Lichter-Konecki U, Diaz G, Merritt II J, Feigenbaum A, Jomphe C, Marier J, Beliveau M, Mauney J, Dickinson K, Martinez A: Ammonia control in children with urea cycle disorders (UCDs); phase 2 
comparison of sodium phenylbutyrate and glycerol phenylbutyrate. Molecular genetics and metabolism 2011, 103:323-9.

[198] Monteleone JP, Mokhtarani M, Diaz GA, Rhead W, Lichter-Konecki U, Berry SA, LeMons C, Dickinson K, Coakley D, Lee B: Population Pharmacokinetic Modeling and Dosing Simulations of Nitrogen-Scavenging Compounds: Disposition of Glycerol Phenylbutyrate and Sodium Phenylbutyrate in Adult and Pediatric Patients with Urea Cycle Disorders. The Journal of Clinical Pharmacology 2013, 53:699-710.

[199] Li H, Wen W, Xu H, Wu H, Xu M, Frank JA, Luo J: 4-Phenylbutyric acid protects against ethanolinduced damage in the developing mouse brain. Alcoholism: Clinical and Experimental Research 2019, 43:69-78.

[200] Reddy SS, Shruthi K, Joy D, Reddy GB: 4-PBA prevents diabetic muscle atrophy in rats by modulating ER stress response and ubiquitin-proteasome system. Chemico-biological interactions 2019, 306:70-7.

[201] Jian L, Lu Y, Lu S, Lu C: Chemical chaperone 4-phenylbutyric acid reduces cardiac ischemia/reperfusion injury by alleviating endoplasmic reticulum stress and oxidative stress. Medical science monitor: international medical journal of experimental and clinical research 2016, 22:5218. [202] Hong Y-p, Deng W-h, Guo W-y, Shi Q, Zhao L, You Y-d, Mei F-c, Zhou Y, Wang C-y, Chen C: Inhibition of endoplasmic reticulum stress by 4-phenylbutyric acid prevents vital organ injury in rat acute pancreatitis. American Journal of Physiology-Gastrointestinal and Liver Physiology 2018, 315:G838-G47. [203] Malo A, Krüger B, Göke B, Kubisch CH: 4-Phenylbutyric acid reduces endoplasmic reticulum stress, trypsin activation, and acinar cell apoptosis while increasing secretion in rat pancreatic acini. Pancreas 2013, 42:92-101.

[204] Hofmann AF: Medical dissolution of gallstones by oral bile acid therapy. The American journal of surgery 1989, 158:198-204.

[205] Jüngst C, Kullak-Ublick GA, Jüngst D: Microlithiasis and sludge. Best practice \& research Clinical gastroenterology 2006, 20:1053-62.

[206] Poupon RE, Balkau B, Eschwège E, Poupon R, Group* UPS: A multicenter, controlled trial of ursodiol for the treatment of primary biliary cirrhosis. New England Journal of Medicine 1991, 324:154854.

[207] Ros E, Navarro S, Bru C, Garcia-Pugés A, Valderrama R: Occult microlithiasis in 'idiopathic'acute pancreatitis: prevention of relapses by cholecystectomy or ursodeoxycholic acid therapy.

Gastroenterology 1991, 101:1701-9.

[208] Testoni PA, Caporuscio S, Bagnolo F, Lella F: Idiopathic recurrent pancreatitis: long-term results after ERCP, endoscopic sphincterotomy, or ursodeoxycholic acid treatment. The American journal of gastroenterology 2000, 95:1702-7.

[209] Seyhun E, Malo A, Schäfer C, Moskaluk CA, Hoffmann R-T, Göke B, Kubisch CH:

Tauroursodeoxycholic acid reduces endoplasmic reticulum stress, acinar cell damage, and systemic inflammation in acute pancreatitis. American Journal of Physiology-Gastrointestinal and Liver Physiology 2011, 301:G773-G82.

[210] Malo A, Krüger B, Seyhun E, Schäfer C, Hoffmann R-T, Göke B, Kubisch CH: Tauroursodeoxycholic acid reduces endoplasmic reticulum stress, trypsin activation, and acinar cell apoptosis while increasing secretion in rat pancreatic acini. American Journal of Physiology-Gastrointestinal and Liver Physiology 2010, 299:G877-G86.

[211] Hetz C, Papa FR: The unfolded protein response and cell fate control. Molecular cell 2018, 69:16981. 
[212] Rozpędek-Kamińska W, Siwecka N, Wawrzynkiewicz A, Wojtczak R, Pytel D, Diehl JA, Majsterek I: The PERK-dependent molecular mechanisms as a novel therapeutic target for neurodegenerative diseases. International journal of molecular sciences 2020, 21:2108.

[213] Boyce M, Bryant KF, Jousse C, Long K, Harding HP, Scheuner D, Kaufman RJ, Ma D, Coen DM, Ron D: A selective inhibitor of elF2 $\alpha$ dephosphorylation protects cells from ER stress. Science 2005, 307:9359.

[214] Aoi K, Nishio A, Okazaki T, Takeo M, Masuda M, Fukui T, Uchida K, Okazaki K: Inhibition of the dephosphorylation of eukaryotic initiation factor $2 \alpha$ ameliorates murine experimental pancreatitis. Pancreatology 2019, 19:548-56.

[215] Cnop M, Ladriere L, Hekerman P, Ortis F, Cardozo AK, Dogusan Z, Flamez D, Boyce M, Yuan J, Eizirik DL: Selective inhibition of eukaryotic translation initiation factor $2 \alpha$ dephosphorylation potentiates fatty acid-induced endoplasmic reticulum stress and causes pancreatic $\beta$-cell dysfunction and apoptosis. Journal of Biological Chemistry 2007, 282:3989-97.

[216] Hughes D, Mallucci GR: The unfolded protein response in neurodegenerative disorders therapeutic modulation of the PERK pathway. Febs j 2019, 286:342-55.

[217] Wang L, Popko B, Tixier E, Roos RP: Guanabenz, which enhances the unfolded protein response, ameliorates mutant SOD1-induced amyotrophic lateral sclerosis. Neurobiology of disease 2014, 71:31724.

[218] Saraswat Ohri S, Mullins A, Hetman M, Whittemore SR: Inhibition of GADD34, the stress-inducible regulatory subunit of the endoplasmic reticulum stress response, does not enhance functional recovery after spinal cord injury. PLoS One 2014, 9:e109703.

[219] Julien C, Lissouba A, Madabattula S, Fardghassemi Y, Rosenfelt C, Androschuk A, Strautman J, Wong C, Bysice A, O'sullivan J: Conserved pharmacological rescue of hereditary spastic paraplegiarelated phenotypes across model organisms. Human molecular genetics 2016, 25:1088-99.

[220] Malerba A, Roth F, Harish P, Dhiab J, Lu-Nguyen N, Cappellari O, Jarmin S, Mahoudeau A, Ythier V, Lainé J: Pharmacological modulation of the ER stress response ameliorates oculopharyngeal muscular dystrophy. Human molecular genetics 2019, 28:1694-708.

[221] Abdulkarim B, Hernangomez M, Igoillo-Esteve M, Cunha DA, Marselli L, Marchetti P, Ladriere L, Cnop M: Guanabenz sensitizes pancreatic $\beta$ cells to lipotoxic endoplasmic reticulum stress and apoptosis. Endocrinology 2017, 158:1659-70.

[222] Tsuji N, Ninov N, Delawary M, Osman S, Roh AS, Gut P, Stainier DY: Whole organism high content screening identifies stimulators of pancreatic beta-cell proliferation. PloS one 2014, 9:e104112.

[223] Janiri L, Hadjichristos A, Buonanno A, Rago R, Mannelli P, De Risio S: Adjuvant trazodone in the treatment of alcoholism: an open study. Alcohol and Alcoholism 1998, 33:362-5.

[224] Roccatagliata G, Albano C, Maffini M, Farelli S: Alcohol withdrawal syndrome: treatment with trazodone. International pharmacopsychiatry 1980, 15:105-10.

[225] Friedmann PD, Rose JS, Swift R, Stout RL, Millman RP, Stein MD: Trazodone for sleep disturbance after alcohol detoxification: a double-blind, placebo-controlled trial. Alcoholism: Clinical and Experimental Research 2008, 32:1652-60.

[226] Lugea A, Waldron RT, French SW, Pandol SJ: Drinking and driving pancreatitis: links between endoplasmic reticulum stress and autophagy. Autophagy 2011, 7:783-5.

[227] Jiang D, Niwa M, Koong AC: Targeting the IRE1 $\alpha-X B P 1$ branch of the unfolded protein response in human diseases. Seminars in cancer biology: Elsevier, 2015. pp. 48-56.

[228] Chien W, Ding L-W, Sun Q-Y, Torres-Fernandez LA, Tan SZ, Xiao J, Lim SL, Garg M, Lee KL, Kitajima $\mathrm{S}$ : Selective inhibition of unfolded protein response induces apoptosis in pancreatic cancer cells. Oncotarget 2014, 5:4881. 
[229] Wu H, Li H, Wen W, Wang Y, Xu H, Xu M, Frank JA, Wei W, Luo J: MANF protects pancreatic acinar cells against alcohol-induced endoplasmic reticulum stress and cellular injury. Journal of HepatoBiliary-Pancreatic Sciences 2021.

[230] Ghosh R, Wang L, Wang ES, Perera BGK, Igbaria A, Morita S, Prado K, Thamsen M, Caswell D, Macias $\mathrm{H}$ : Allosteric inhibition of the IRE1 $\alpha$ RNase preserves cell viability and function during endoplasmic reticulum stress. Cell 2014, 158:534-48.

[231] Maly DJ, Papa FR: Druggable sensors of the unfolded protein response. Nature chemical biology 2014, 10:892-901.

[232] Gallagher CM, Garri C, Cain EL, Ang KK-H, Wilson CG, Chen S, Hearn BR, Jaishankar P, Aranda-Diaz A, Arkin MR: Ceapins are a new class of unfolded protein response inhibitors, selectively targeting the ATF6 $\alpha$ branch. elife 2016, 5:e11878.

[233] Xu W, Lu X, Zheng J, Li T, Gao L, Lenahan C, Shao A, Zhang J, Yu J: Melatonin protects against neuronal apoptosis via suppression of the ATF6/CHOP pathway in a rat model of intracerebral hemorrhage. Frontiers in neuroscience 2018, 12:638.

[234] Chen Y, Zhang J, Zhao Q, Chen Q, Sun Y, Jin Y, Wu J: Melatonin induces anti-inflammatory effects to play a protective role via endoplasmic reticulum stress in acute pancreatitis. Cellular Physiology and Biochemistry 2016, 40:1094-104.

[235] Zhao Q, Zhang H, Huang J, Yu H, Li J, Che Q, Sun Y, Jin Y, Wu J: Melatonin attenuates the inflammatory response via inhibiting the C/EBP homologous protein-mediated pathway in taurocholateinduced acute pancreatitis. International journal of molecular medicine 2018, 42:3513-21.

[236] Blackwood EA, Azizi K, Thuerauf DJ, Paxman RJ, Plate L, Kelly JW, Wiseman RL, Glembotski CC: Pharmacologic ATF6 activation confers global protection in widespread disease models by reprograming cellular proteostasis. Nature communications 2019, 10:1-16.

[237] Jin J-K, Blackwood EA, Azizi K, Thuerauf DJ, Fahem AG, Hofmann C, Kaufman RJ, Doroudgar S, Glembotski CC: ATF6 decreases myocardial ischemia/reperfusion damage and links ER stress and oxidative stress signaling pathways in the heart. Circulation research 2017, 120:862-75.

[238] Yu Z, Sheng H, Liu S, Zhao S, Glembotski CC, Warner DS, Paschen W, Yang W: Activation of the ATF6 branch of the unfolded protein response in neurons improves stroke outcome. Journal of Cerebral Blood Flow \& Metabolism 2017, 37:1069-79.

[239] Hetz C, Chevet E, Oakes SA: Proteostasis control by the unfolded protein response. Nature cell biology 2015, 17:829-38.

[240] Plate L, Wiseman RL: Regulating secretory proteostasis through the unfolded protein response: from function to therapy. Trends in cell biology 2017, 27:722-37.

[241] Plate L, Cooley CB, Chen JJ, Paxman RJ, Gallagher CM, Madoux F, Genereux JC, Dobbs W, Garza D, Spicer TP: Small molecule proteostasis regulators that reprogram the ER to reduce extracellular protein aggregation. elife 2016, 5:e15550.

[242] Kudo T, Kanemoto S, Hara H, Morimoto N, Morihara T, Kimura R, Tabira T, Imaizumi K, Takeda M: A molecular chaperone inducer protects neurons from ER stress. Cell Death \& Differentiation 2008, 15:364-75.

[243] Oida Y, Izuta H, Oyagi A, Shimazawa M, Kudo T, Imaizumi K, Hara H: Induction of BiP, an ERresident protein, prevents the neuronal death induced by transient forebrain ischemia in gerbil. Brain research 2008, 1208:217-24.

[244] Prachasilchai W, Sonoda H, Yokota-Ikeda N, Ito K, Kudo T, Imaizumi K, Ikeda M: The Protective Effect of a Newly Developed Molecular Chaperone-Inducer Against Mouse Ischemic Acute Kidney Injury. Journal of pharmacological sciences 2009:0901280192-.

[245] Braakman I, Bulleid NJ: Protein folding and modification in the mammalian endoplasmic reticulum. Annual review of biochemistry 2011, 80:71-99. 
[246] Petersen $\mathrm{OH}$, Sutton R: Ca2+ signalling and pancreatitis: effects of alcohol, bile and coffee. Trends in pharmacological sciences 2006, 27:113-20.

[247] Petersen OH, Tepikin A, Gerasimenko JV, Gerasimenko OV, Sutton R, Criddle D: Fatty acids, alcohol and fatty acid ethyl esters: toxic Ca2+ signal generation and pancreatitis. Cell calcium 2009, 45:634-42. [248] Petersen $\mathrm{OH}$, Sutton R: Ca2+ signalling and pancreatitis: effects of alcohol, bile and coffee. Trends Pharmacol Sci 2006, 27:113-20.

[249] Wen L, Voronina S, Javed MA, Awais M, Szatmary P, Latawiec D, Chvanov M, Collier D, Huang W, Barrett J: Inhibitors of ORAI1 prevent cytosolic calcium-associated injury of human pancreatic acinar cells and acute pancreatitis in 3 mouse models. Gastroenterology 2015, 149:481-92. e7.

[250] Gerasimenko JV, Gryshchenko O, Ferdek PE, Stapleton E, Hébert TO, Bychkova S, Peng S, Begg M, Gerasimenko OV, Petersen $\mathrm{OH}$ : $\mathrm{Ca} 2+$ release-activated $\mathrm{Ca} 2+$ channel blockade as a potential tool in antipancreatitis therapy. Proceedings of the National Academy of Sciences of the United States of America 2013, 110:13186-91.

[251] Criddle DN, Raraty MG, Neoptolemos JP, Tepikin AV, Petersen OH, Sutton R: Ethanol toxicity in pancreatic acinar cells: mediation by nonoxidative fatty acid metabolites. Proceedings of the National Academy of Sciences 2004, 101:10738-43.

[252] Waldron RT, Chen Y, Pham H, Go A, Su HY, Hu C, Wen L, Husain SZ, Sugar CA, Roos J: The Orai Ca2+ channel inhibitor CM4620 targets both parenchymal and immune cells to reduce inflammation in experimental acute pancreatitis. The Journal of physiology 2019, 597:3085-105.

[253] Rahman S, Rahman T: Unveiling some FDA-approved drugs as inhibitors of the store-operated Ca 2+ entry pathway. Scientific reports 2017, 7:1-13.

[254] Pandol SJ, Gorelick FS, Gerloff A, Lugea A: Alcohol abuse, endoplasmic reticulum stress and pancreatitis. Digestive diseases 2010, 28:776-82.

[255] Gukovsky I, Reyes CN, Vaquero EC, Gukovskaya AS, Pandol SJ: Curcumin ameliorates ethanol and nonethanol experimental pancreatitis. American Journal of Physiology-Gastrointestinal and Liver Physiology 2003.

[256] Wang Y, Bu C, Wu K, Wang R, Wang J: Curcumin protects the pancreas from acute pancreatitis via the mitogen-activated protein kinase signaling pathway. Molecular medicine reports 2019, 20:3027-34. [257] Yu W-G, Xu G, Ren G-J, Xu X, Yuan H-Q, Qi X-L, Tian K-L: Preventive action of curcumin in experimental acute pancreatitis in mouse. The Indian journal of medical research 2011, 134:717. [258] Gupta SC, Patchva S, Aggarwal BB: Therapeutic roles of curcumin: lessons learned from clinical trials. The AAPS journal 2013, 15:195-218.

[259] Sasaki H, Sunagawa Y, Takahashi K, Imaizumi A, Fukuda H, Hashimoto T, Wada H, Katanasaka Y, Kakeya H, Fujita M: Innovative preparation of curcumin for improved oral bioavailability. Biological and Pharmaceutical Bulletin 2011, 34:660-5.

[260] Kanai M: Therapeutic applications of curcumin for patients with pancreatic cancer. World journal of gastroenterology: WJG 2014, 20:9384.

[261] Kanai M, Yoshimura K, Asada M, Imaizumi A, Suzuki C, Matsumoto S, Nishimura T, Mori Y, Masui T, Kawaguchi Y: A phase I/II study of gemcitabine-based chemotherapy plus curcumin for patients with gemcitabine-resistant pancreatic cancer. Cancer chemotherapy and pharmacology 2011, 68:157-64. [262] Dhillon N, Aggarwal BB, Newman RA, Wolff RA, Kunnumakkara AB, Abbruzzese JL, Ng CS, Badmaev $\mathrm{V}$, Kurzrock R: Phase II trial of curcumin in patients with advanced pancreatic cancer. Clinical cancer research 2008, 14:4491-9.

[263] Rose P, Fraine E, Hunt L, Acheson D, Braganza J: Dietary antioxidants and chronic pancreatitis. Human nutrition Clinical nutrition 1986, 40:151-64.

[264] De Waele B, Vierendeels T, Willems G: Vitamin status in patients with acute pancreatitis. Clinical Nutrition 1992, 11:83-6. 
[265] Kalvaria I, Labadarios D, Shephard GS, Visser L, Marks IN: Biochemical vitamin E deficiency in chronic pancreatitis. International journal of pancreatology : official journal of the International Association of Pancreatology 1986, 1:119-28.

[266] Du WD, Yuan ZR, Sun J, Tang JX, Cheng AQ, Shen DM, Huang CJ, Song XH, Yu XF, Zheng SB: Therapeutic efficacy of high-dose vitamin $C$ on acute pancreatitis and its potential mechanisms. World J Gastroenterol 2003, 9:2565-9.

[267] Monteiro TH, Silva CS, Ambrosio LMCS, Zucoloto S, Vannucchi H: Vitamin E alters inflammatory gene expression in alcoholic chronic pancreatitis. Lifestyle Genomics 2012, 5:94-105.

[268] Hetz C, Saxena S: ER stress and the unfolded protein response in neurodegeneration. Nature Reviews Neurology 2017, 13:477-91.

[269] Elfiky AA, Baghdady AM, Ali SA, Ahmed MI: GRP78 targeting: Hitting two birds with a stone. Life sciences 2020:118317.

[270] Gorbatyuk MS, Gorbatyuk OS: The molecular chaperone GRP78/BiP as a therapeutic target for neurodegenerative disorders: a mini review. Journal of genetic syndrome \& gene therapy $2013,4$. [271] Ha Y, Liu W, Liu H, Zhu S, Xia F, Gerson JE, Azhar NA, Tilton RG, Motamedi M, Kayed R: AAV2mediated GRP78 transfer alleviates retinal neuronal injury by downregulating ER stress and tau oligomer formation. Investigative ophthalmology \& visual science 2018, 59:4670-82.

[272] Gorbatyuk MS, Knox T, LaVail MM, Gorbatyuk OS, Noorwez SM, Hauswirth WW, Lin JH, Muzyczka $\mathrm{N}$, Lewin AS: Restoration of visual function in $\mathrm{P} 23 \mathrm{H}$ rhodopsin transgenic rats by gene delivery of BiP/Grp78. Proceedings of the National Academy of Sciences 2010, 107:5961-6.

[273] Ghaderi S, Ahmadian S, Soheili ZS, Ahmadieh H, Samiei S, Kheitan S, Pirmardan ER: AAV delivery of GRP78/BiP promotes adaptation of human RPE cell to ER stress. Journal of cellular biochemistry 2018, 119:1355-67.

[274] Gorbatyuk MS, Shabashvili A, Chen W, Meyers C, Sullivan LF, Salganik M, Lin JH, Lewin AS, Muzyczka N, Gorbatyuk OS: Glucose regulated protein 78 diminishes $\alpha$-synuclein neurotoxicity in a rat model of Parkinson disease. Molecular Therapy 2012, 20:1327-37.

[275] Teodoro-Morrison T, Schuiki I, Zhang L, Belsham DD, Volchuk A: GRP78 overproduction in pancreatic beta cells protects against high-fat-diet-induced diabetes in mice. Diabetologia 2013, 56:1057-67.

[276] Ye R, Mareninova OA, Barron E, Wang M, Hinton DR, Pandol SJ, Lee AS: Grp78 heterozygosity regulates chaperone balance in exocrine pancreas with differential response to cerulein-induced acute pancreatitis. The American journal of pathology 2010, 177:2827-36.

[277] Zuleta A, Vidal RL, Armentano D, Parsons G, Hetz C: AAV-mediated delivery of the transcription factor XBP1s into the striatum reduces mutant Huntingtin aggregation in a mouse model of Huntington's disease. Biochemical and biophysical research communications 2012, 420:558-63.

[278] Valenzuela V, Collyer E, Armentano D, Parsons G, Court F, Hetz C: Activation of the unfolded protein response enhances motor recovery after spinal cord injury. Cell death \& disease 2012, 3:e272-e. [279] Sado M, Yamasaki Y, Iwanaga T, Onaka Y, Ibuki T, Nishihara S, Mizuguchi H, Momota H, Kishibuchi $R$, Hashimoto T: Protective effect against Parkinson's disease-related insults through the activation of XBP1. Brain research 2009, 1257:16-24.

[280] Valdés P, Mercado G, Vidal RL, Molina C, Parsons G, Court FA, Martinez A, Galleguillos D, Armentano D, Schneider BL, Hetz C: Control of dopaminergic neuron survival by the unfolded protein response transcription factor XBP1. Proceedings of the National Academy of Sciences 2014, 111:6804-9. [281] Vidal RL, Sepulveda D, Troncoso-Escudero P, Garcia-Huerta P, Gonzalez C, Plate L, Jerez C, Canovas J, Rivera CA, Castillo V: Enforced dimerization between XBP1s and ATF6f enhances the protective effects of the UPR in models of neurodegeneration. Molecular Therapy 2021, 29:1862-82. 
[282] Tan J-H, Cao R-C, Zhou L, Zhou Z-T, Chen H-J, Xu J, Chen X-M, Jin Y-C, Lin J-Y, Zeng J-L: ATF6 aggravates acinar cell apoptosis and injury by regulating p53/AIFM2 transcription in severe acute pancreatitis. Theranostics 2020, 10:8298.

[283] Pitale PM, Gorbatyuk O, Gorbatyuk M: Neurodegeneration: keeping ATF4 on a tight leash. Frontiers in cellular neuroscience 2017, 11:410.

[284] Bhootada Y, Kotla P, Zolotukhin S, Gorbatyuk O, Bebok Z, Athar M, Gorbatyuk M: Limited ATF4 expression in degenerating retinas with ongoing ER stress promotes photoreceptor survival in a mouse model of autosomal dominant retinitis pigmentosa. PLoS One 2016, 11:e0154779.

[285] Deng X, He Y, Miao X, Yu B: ATF4-mediated histone deacetylase HDAC1 promotes the progression of acute pancreatitis. Cell death \& disease 2021, 12:1-14.

[286] Lindholm P, Peränen J, Andressoo J-O, Kalkkinen N, Kokaia Z, Lindvall O, Timmusk T, Saarma M: MANF is widely expressed in mammalian tissues and differently regulated after ischemic and epileptic insults in rodent brain. Molecular and Cellular Neuroscience 2008, 39:356-71.

[287] Lindahl M, Saarma M, Lindholm P: Unconventional neurotrophic factors CDNF and MANF:

Structure, physiological functions and therapeutic potential. Neurobiology of disease 2017, 97:90-102. [288] Wang Y, Wen W, Li H, Clementino M, Xu H, Xu M, Ma M, Frank J, Luo J: MANF is neuroprotective against ethanol-induced neurodegeneration through ameliorating ER stress. Neurobiology of Disease 2021, 148:105216.

[289] LindahI M, Danilova T, Palm E, Lindholm P, Võikar V, Hakonen E, Ustinov J, Andressoo J-O, Harvey BK, Otonkoski T: MANF is indispensable for the proliferation and survival of pancreatic $\beta$ cells. Cell reports 2014, 7:366-75.

[290] Danilova T, Belevich I, Li H, Palm E, Jokitalo E, Otonkoski T, Lindahl M: MANF is required for the postnatal expansion and maintenance of pancreatic $\beta$-cell mass in mice. Diabetes 2019, 68:66-80. [291] Hakonen E, Chandra V, Fogarty CL, Yu NY-L, Ustinov J, Katayama S, Galli E, Danilova T, Lindholm P, Vartiainen A: MANF protects human pancreatic beta cells against stress-induced cell death. Diabetologia 2018, 61:2202-14.

[292] Montaser H, Patel KA, Balboa D, Ibrahim H, Lithovius V, Näätänen A, Chandra V, Demir K, Acar S, Ben-Omran T: Loss of MANF causes childhood-onset syndromic diabetes due to increased endoplasmic reticulum stress. Diabetes 2021, 70:1006-18.

[293] Galli E, Härkönen T, Sainio MT, Ustav M, Toots U, Urtti A, Yliperttula M, Lindahl M, Knip M, Saarma $\mathrm{M}$ : Increased circulating concentrations of mesencephalic astrocyte-derived neurotrophic factor in children with type 1 diabetes. Scientific reports 2016, 6:1-11.

[294] Airavaara M, Shen H, Kuo CC, Peranen J, Saarma M, Hoffer B, Wang Y: Mesencephalic astrocytederived neurotrophic factor reduces ischemic brain injury and promotes behavioral recovery in rats. The Journal of comparative neurology 2009, 515:116-24.

[295] Airavaara M, Chiocco MJ, Howard DB, Zuchowski KL, Peranen J, Liu C, Fang S, Hoffer BJ, Wang Y, Harvey BK: Widespread cortical expression of MANF by AAV serotype 7: localization and protection against ischemic brain injury. Experimental neurology 2010, 225:104-13.

[296] Yang W, Shen Y, Chen Y, Chen L, Wang L, Wang H, Xu S, Fang S, Fu Y, Yu Y, Shen Y: Mesencephalic astrocyte-derived neurotrophic factor prevents neuron loss via inhibiting ischemia-induced apoptosis. Journal of the neurological sciences 2014, 344:129-38.

[297] Wang XY, Song MM, Bi SX, Shen YJ, Shen YX, Yu YQ: MRI Dynamically Evaluates the Therapeutic Effect of Recombinant Human MANF on Ischemia/Reperfusion Injury in Rats. International journal of molecular sciences 2016, 17.

[298] Teppo J, Vaikkinen A, Stratoulias V, Mätlik K, Anttila JE, Smolander OP, Pöhö P, Harvey BK, Kostiainen R, Airavaara M: Molecular profile of the rat peri-infarct region four days after stroke: Study with MANF. Experimental neurology 2020, 329:113288. 
